\title{
Annelerin Çocukluk Örselenmelerinin Çocuğa Bakım Verme Davranışları Üzerindeki Etkisi ve Çocuk İçin Riskleri ${ }^{1}$
}

\section{The Effect of Maternal Childhood Maltreatment on Maternal Caregiving and Risk for the Child}

\author{
Kübra Şahin İpek ${ }^{1 *}$, Sultan Tarlaci ${ }^{2}$ \\ ${ }^{1}$ Uzm.Psikolog, Kocaeli Adliyesi, pskkubra@gmail.com, orcid.org/0000-0002-7781-098X *Sorumlu Yazar \\ ${ }^{2}$ Prof.Dr., Üsküdar Üniversitesi, sultan.tarlaci@uskudar.edu.tr., orcid.org/0000-0001-7634-1467
}

Geliş tarihi/Received : 06.05.2021 Kabul tarihi/Accepted: 26.10.2021 Yayın tarihi/Published: 30.12.2021

\section{ÖZET}

Çocuklukta yaşanan örselenme yaşantılarının yaşam boyu süren bedensel ve ruhsal etkileri bulunmaktadır. $\mathrm{Bu}$ etkilerden biri de ebeveynlik davranışları üzerinedir. Bu araştırma ile çocukluk örselenmelerinin, annelik davranışları üzerindeki etkisi ve çocuğun gelişiminde ortaya çıkabilecek risk faktörleri, annenin duygu düzenleme becerisi ve çocuğuyla kurduğu ilişkinin niteliği üzerinden araştırılması hedeflenmiştir. Nörogelişimsel yaklaşımın esas alındığı araştırmaya,4-6 yaş aralığında problem davranışlar sergilediği gözlemlenen çocukların $(\mathrm{N}=75)$ anneleri katılmıştır. Katılımcı annelere Çocukluk Örselenme Yaşantıları Ölçeği (ÇÖYÖ), Duygu Düzenleme Güçlüğü Ölçeği (DDGÖ)-Kısa Form ve Çocuk Ana-Baba İlişki Ölçeği uygulanmıştır. İlişki ölçeği yakınlık boyutu ters kodlanmıştır ve değişkenler arasındaki ilişkiler ANOVA, korelasyon, ki-kare ve hiyerarşik regresyon analizleri ile yorumlanmıştır. Uygulanan analizler sonucunda; katılımcıların en yüksek oranda duygusal ihmal ve istismar yaşantısı bildirdiği görülmüştür. Katılımcı annelerde örselenme yaşantısının varlığı arttıkça duygu düzenleme güçlüğünde artış olduğu $(\mathrm{r}=.40 ; \mathrm{p}<.01)$, anne-çocuk ilişkisinin niteliğinde ise DDGÖ açıklı (duygusal tepkilerin anlaşılamaması) alt boyutunun yordama gücü $(\operatorname{Beta}=.43 ; \mathrm{p}<.01)$ bulunduğu görülmüsştür. Cinsel istismar yaşantısının varlığı ile anne-çocuk ilişkisinin yakınlık boyutu $(\mathrm{r}=.30 ; \mathrm{p}<.01)$ arasında ve duygu düzenleme güçlüğü ile anne-çocuk ilişkisinin çatışma boyutu $(\mathrm{r}=.37 ; \mathrm{p}<.01)$ arasında pozitif ilişki olduğu bulgularına ulaşılmıştır. Anne-çocuk iliş̧isinin nörogelişimsel mekanizmasını anlamak, annenin ve gelişmekte olan çocuğun duygusal ve bilişsel sağlığı üzerinde daha etkili adımlar atılmasını sağlayacaktır. Bu adımlar, çocukluk dönemi örselenmelerinin gelecek kuşaklara etkisinin kırılabilmesi için gerekli erken müdahalenin yapılabilmesi adına önemli görünmektedir.

Anahtar Kelimeler: Çocuk ihmal ve istismarı, annelerin çocukluk çağı örselenmeleri, erken dönem beyin gelişimi, duygu düzenlemenin nörogelişimi, anne bakımı

\begin{abstract}
The childhood maltreatment has lifelong physical and mental effects. One of these effects is on parenting behaviors. This study aimed to investigate the impact of childhood maltreatment on maternal caregiving and risk of the child development. This research uses neurodevelopmental approach and focuses on the mother's emotional regulation capacity and mother-child relationships. The data was collected from the mothers of children (75) who were observed to show problematic behaviors at 4-6 years old. 3 measurement scales were here: Childhood Maltreatment Quesstionnnaire (CMQ), Difficulties in Emotion Regulation Scale Brief Form (DERS-16), ChildParent Relationship Scale. Closness sub-scale of the Child-Parent Relationship Scale was reversed and variables were tested by anova, corelation, chi-square and hierarchical regression. The participants reported that emotional neglect and abuse rate was the highest in maltreatment. It was seen that there was an increase in the difficulties in emotion regulation when the maltreatment experiences increased $(r=.40 ; p<.01)$. Clarity sub-dimension of DERS16 predicted the quality of the relationships of mothers with their children (Beta $=.43 ; \mathrm{p}<.01$ ). It was found that there were positive correlations between the existence of maltreatment experience and the closness of mother-chid relationship $(\mathrm{r}=.30 ; \mathrm{p}<.01)$ and between the emotion regulation difficulty and conflict dimension of mother-child relationship $(\mathrm{r}=.37 ; \mathrm{p}<.01)$. This study also showed that, understanding the neurodevelopmental mechanism of the relationship of mother and child would provide to take effective steps on the emotional and cognitive health of mother and growing child. These steps seem to be important for early intervention in order to break the impact of childhood maltreatment on next generations.
\end{abstract}

Keywords: Child abuse and neglect, maternal childhood maltreatment, early brain development, neurodevelopment of emotional regulation, maternal caregiving

\footnotetext{
${ }^{1} \mathrm{Bu}$ çalışma ikinci yazarın danışmanlığındaki birinci yazarın yüksek lisans tezinden üretilmiştir.
} 


\section{GíRiş}

Dünya Sağlık Örgütü'ne göre çocuğa kötü muamele; 18 yaşın altında maruz kalınan, fiilen ya da potansiyel olarak çocuğun sağlığına, gelişimine, yaşamına ve onuruna zarar veren fiziksel, duygusal, cinsel istismarı, ihmali ve ticari sömürüyü kapsar (World Health Organization, 2016). Her yıl 15 yaşın altında 40 milyon çocuk ihmal ve istismar mağduru olmaktadır (United Nations International Children's Emergency Fund, 2008). Ülkemizde UNICEF işbirliğiyle yapılan çalışmada, 7-18 yaş arası çocukların \%51 düzeyinde duygusal istismara, \%43 düzeyinde fiziksel istismara ve $\% 3$ düzeyinde cinsel istismara ve $\% 25$ oranında ihmale maruz kaldığ saptanmıştır. Yine bu çocukların \%56 oranında fiziksel istismara, \%49 oranında duygusal istismara ve $\% 10$ oranında cinsel istismara tanıklık ettikleri rapor edilmiştir (UNICEF-Türkiye, 2010).

Çocuğun bakım ve korunmasından sorumlu kişilerin çocuğa kötü muamelesi çocuk istismarı anlamına gelirken, bu kişilerin çocuğun bakım ve korunmasını yeterli ölçüde sağlayamamaları çocuk ihmali olarak değerlendirilmektedir (Lynch, 1999). Çocuk istismarı konusunun literatüre ilk girişi 1946 yılında olup, kafa travması ve sarsılmaya bağlı fiziksel bulgularla ilişkisi ortaya çıkarılmıştır ancak uzun yıllar konuya gereken dikkat verilmemiştir (Kara, Biçer ve Gökalp, 2004). Çocukluk çağı olumsuz yaşantılarına dair en kapsamlı ve dikkat çekici çalışma ise, 1997 yılında 17000'den fazla kişiyle yapılmış olan olumsuz çocukluk deneyimleri çalışmasıdır. Bu çalışma ile olumsuz çocukluk yaşantılarına maruz kalma arttıkça yetişkinlikte, depresyon ve intihar girişimi, cinsel sağlık sorunları, obezite, alkolizm, uyuşturucu bağımlılığı, kalp ve akciğer hastalıkları riski ile güçlü bir ilişkisi olduğu gösterilmiştir (Felitti, 2009). Çocukluk travmalarını önemli kılan bir diğer faktör, olumsuz etkilerinin yalnızca maruz kalan kişiyle sınırlı olmamasıdır. Örselenmelerin kuşaklararası bir etki yarattığı konusuna ilk vurgu yapan makale, 1975 yılında Fraiberg ve arkadaşları tarafından yayınlanmıştır. Söz konusu makalede, çocukluk örselenmelerinin olumsuz sonuçlarının, bakım verme yoluyla çocuğa aktarıldığı ve etkisinin nesiller boyu devam ettiği anlatılmıştır (Fraiberg, Adelson ve Shapiro, 1975).

Çocuğa kötü muamele her sosyoekonomik düzeyden ailenin içinde görülebilmekle birlikte ailesel işlev bozukluğunun bir göstergesi sayılmaktadır (De Bellis, 2005). Kötü muamelenin yaşandığı aileler üzerine yapılan çalışmalar, bu ailelerdeki anne ve babaların diğer ebeveynlere nazaran çocuklarıyla duygusal etkileşimlerinin içeriği ve sıklığı bakımından farklılıklar gösterdiklerini ve daha az olumlu duygu ifade ettiklerini bulgulamışlardır (Pollak, Cicchetti, Hornung ve Reed, 2000).

Sarı, Ardahan ve Öztornacı (2016), son 10 yılı kapsayan analiz çalışmalarında, fiziksel istismara maruz kalmanın yarattığı risk faktörlerinin başında yasadışı madde kullanımının geldiğini, cinsel ve duygusal istismar sonucunda ise en fazla zihinsel rahatsılık riski doğduğunu saptamışlardır. Şiddeti sorun çözme yöntemi olarak kullanma ve sosyal ilişkilerde bozukluk fiziksel istismarın sonuçları arasında sayılırken, cinsel istismarın sonuçları arasında ilişki kurma ve sürdürebilme becerisinde bozulma ve depresyon sayılmaktadır. Duygusal istismar ise ileriye dönük kişilik bozukluklarının gelişiminde önemli bir risk etmeni olarak görülmektedir (Gökler ve Taner, 2004).

İhmal ya da istismarın bakım veren kişi tarafından erken dönemde uygulanmış olması, tekrarlayıcı ve/veya uzun süreli nitelikte olması yaşanan örselenmeye gelişimsel travma özelliği atfetmiş olur. Gelişimsel travmayı diğer travmalardan ayıran özelliği, bakım veren ve bebek arasında oluşan bağlanma örüntüsünün ileride kurulacak ilişkiler için bir model oluşturacak ve kişinin alg1 ve beklentilerini şekillendirerek duygu ve düşüncelerine önderlik edecek olmasıdır (Firat ve Baskak, 2012). 
Diğer primatlarla karşılaştırıldığında insan yavrusu çok daha az olgunlaşmış bir beyinle dünyaya gelir ve hayatta kalmak için uzun süre bakıcılara bağımlıdır. Bağımlı olduğu bu dönem, fiziksel, zihinsel, duygusal ve sosyal gelişimin çok hızlı olduğu ve yetişkinlik döneminde sahip olacağı beynin neredeyse \%90'ını zenginleştirdiği dönemdir (Bertan, Haznedaroğlu, Koln, Yudakök ve Güçiz, 2009; Perry, 2000). Beynin sağliklı gelişiminin önemli bileşenleri olan, miyelinizasyon, sinaptogenez, plastisite, duygu ve davranışların düzenlenmesi gibi süreçler, bilgi, iletişim ve deneyimlerle zenginleşirler. Aksi takdirde, yetersiz duyusal-motor uyarım, gerilim, stres ve toksik stres beyin gelişimini olumsuz yönde etkileyecektir (Shore, 2012; Tanrıdağ, 2018). Shonkoff, koruyucu bir anne çocuk ilişkisinin yokluğunun, strese yanıt sistemlerinde uzayan bir aktivasyon yaratmakta olduğunu ve bunun çocuklarda "toksik stres" olarak tanımlandığını aktarmaktadır (akt.; Bertan ve ark., 2009). Toksik stres, nöron bağlantılarının yeterli düzeyde oluşamamasına ve böylece beynin mimarisinin değişmesine sebep olmaktadır (Bertan ve ark., 2009). Çocuklukta kötü muamelenin nörogelişimsel süreçlerine vurgu yapan Perry'e göre, bebekler ve çocuklar en çok aile içinde şiddete maruz kalır ya da tanık olurlar. Bu çocuklar içinde bulundukları tehdit ve korku atmosferine uyum sağlamak zorunda kalır. Bu uyum ise nörofizyolojik süreçlerde gerçekleşerek çocuğun fizyolojik, duygusal, davranışsal, bilişsel ve sosyal işlevlerinde meydana gelecek fonksiyonel değişimlerin temel nörogelişimsel zeminini oluşturur. $\mathrm{Bu}$ yönüyle erken dönemde gelişmekte olan beyin strese son derece duyarlıdır (Perry, 2001; Perry, 2002).

Beyin, çocukluk döneminde tamamen işlevsel hale gelir ve "kullan ya da kaybet" ilkesine göre çalışır. Beynin üst bölgelerinin sağlıklı gelişimi ise alt bölgelerin sağlıklı işleyişine bağlıdır (Perry 2002; Perry, 2009). Bu haliyle Perry, kötü muamele görmüş çocukların çoğunluğundaki problemin, beyindeki dağınık veya zayıf düzenlenmiş ağ bağlantıları kaynaklı olduğunu vurgular (Perry, 2000; Perry, 2009).

Duygu ve duyguyu düzenleyen nörolojik süreçler, duyulardan soyut akıl yürütmeye varana kadarki süreçlerde meydana gelir. Beyinde bu süreç, limbik yap1 ile prefrontal bölgenin karşılıklı işleyişinde çalışılmış, limbik bölgenin uyarıcının değeri ve anlamı konusunda uzmanlaşmış olduğu, orta prefrontal bölgenin ise anlamın değerlendirilmesi, sosyal bilgi işlemleme, üst bilişsel işlevler ve bedensel tepkilerin koordineli bir şekilde bütünleşmesini sağladığı görülmüştür. Duyguya dair açıklamaların ortak kabulü, duygunun çevreyle sürekli etkileşim halinde olduğu ve bu etkileşimlerin fizyolojik değişimlerin ve bilişsel süreçlerin ortaya çıkmasında çok büyük etkisi olduğudur. Bu yönüyle duygu, içsel ve dişsal etkilenmeyi sağlayarak bizi eyleme hazırlar, bir ruh hali meydana getirir ve kişilerarası etkileşimi açığa çıkarır. Sonuçta, duygu ve duygunun düzenlenmesi bir bütünün parçaları olarak görülür (Siegel, 2018).

Duygunun düzenlenmesinde etkin olan limbik sisteme ait amigdala ve hipokampüs, strese yanıt oluşturur. Yapılan araştırmalarda, tekrarlanan stresin bu parçaların sinaptik yapısını ve aktivasyonunu değiştirdiği görülmektedir. Hipokampüsteki hasar, hafıza ve öğrenmeyle ilişkili gözlemlenen bazı problemlerle ve travma sonrası stres bozukluğu (TSSB) ile ilişkilendirilirken, amigdala hasarı sosyal uyaranların önemini değerlendirmede sorunlara yol açmaktadır (Perry, 2001; Hanson ve ark., 2014). Bu yönüyle çocuklukta kronik strese maruz kalma, prefrontal korteks aktivasyonuna zarar verir ve etkinliğini zayıflatır, amigdalada ise etkinlik artışı görülür (De Bellis, 2005; Karabekiroğlu, Karabekiroğlu, Cömert ve Topçuoğlu, 2007). Hanson ve arkadaşları (2014), şiddet ve ihmal gibi yoğun stres altında yaşamış 12 yaşında çocuklarla yaptıkları çalışmada, iyi koşullarda bulunmuş çocuklara nazaran bu çocukların daha küçük hacimli amigdala ve hipokampüse sahip olduklarını bulgulamışlardır. Tottenham ve arkadaşları (2011) tarafından yapılan çalışmada, koruma altında bulunan 10 yaşlarındaki çocuklarda kontrol grubuna nazaran artmış amigdala aktivitesi ve amigdala ile prefrontal korteks arasında 
azalmış beyaz madde tespit edilmiştir. Yine bu çocukların göz teması süresi anlamlı olarak daha az bulunmuştur.

Prefrontal Kortekse ait bölümlerden olan Medial prefrontal korteks, sosyal biliş, olumsuz duyguların düzenlenmesi ve amigdala aktivitesinin baskılanmasında işlev görürken, Orbitofrontal korteks, uyarıcının değerlendirilmesi, homeostatik düzenleme, özellikle korkuya dair duygusal bellek ve empati gibi işlevleri yerine getirmektedir. Orbitofrontalin bu yönüyle bağlanma süreçlerine dahil olduğu ve gelişiminde bağlanılan kişi ile göz teması, yüz yüze iletişim ve uyumlanma sırasındaki uyarılmaların niteliğinin oldukça önemli olduğu görülmüştür (Schore, 2013; Siegel, 2018). Fonksiyonel nörogörüntüleme çalışmaları, duygu, dikkat, motivasyon ve empati için sağlıklı işlemesine ihtiyaç duyulan alt ve üst kortikal beyin bölgelerinin, bebeğe ait uyaranları, besleme ve bakım davranışlarını da düzenlediğini ve bu bölgelerin aktivasyonunun etkili ebeveynlik için çok önemli olduğunu göstermektedir (Swain, 2008).

Bebekler ihtiyaçlarını karşılamak için dış stres düzenleyicileri olarak bakım verenlerine bağımlıdırlar. Birincil bakıcının besleyici, duyarlı, tutarlı ve öngörülebilir bakımı sayesinde bebeğin beyninde kullanıma bağlı oluşan nöral aktiviteye uygun olarak, uyumlu ve esnek stres yanıt sistemi inşa edilecektir. Ancak, bakım verenin depresif, stresli, tutarsız ve ilgisiz olduğunda bu sistem ağları anormal olarak gelişir ve ortaya, gelecekteki stres faktörlerine karşı baş etme güçlüğü yaşayan, yardımcı olabilecek ilişkisel desteklerden yararlanamayan bir çocuk çıkar (Perry, 2009). Sosyal ilişkilere hazırlık olan bu süreç, çocuğun duyguları tanıması, sosyal ip uçlarını yorumlayabilmesi ve davranışsal cevap oluşturabilmesi için önemlidir (Pollak ve ark., 2000).

Racine, Plamondon, Madigan, McDonald ve Tough (2018), annelerin çocukluk örselenme yaşantılarının doğum öncesi ve doğum sonrası üzerine biyolojik ve psikolojik etkisini incelemek amacıyla, ortalama 31 yaşlarında 1994 kadın katılımcı ile hamilelik döneminde ve bebeklerinin 4. ve 12. ayında psikometrik ölçümler yapmışlardır. Bu ölçümler sırasıyla, doğum riski, bebeğe yönelik düşmanca davranışlar ve bebeğin gelişim düzeyi hakkında bilgi almayı amaçlamıştır. Annenin örselenmişlik öyküsü arttıkça hamilelikte sağlık sorunlarının arttığ yine bebeğin de sağlık sorunlarıyla doğma riskinin arttığı görülmüştür. Ayrıca, annenin örselenmişliğine bağlı biyolojik ve psikolojik risklerin kümülatif bir etki yaparak bebeğin 12 . ayı dolaylarında olumsuz gelişimsel çıtılarının izlenebildiği görülmüştür. Annede örselenmişliğe bağlı gelişen risklerin hamilelik döneminde fizyolojik tepkiler olarak ortaya çıktığı, doğum sonrasında ise davranışsal tepkiler olarak ortaya çıktığı sonucuna ulaşılmıştır.

Kim ve arkadaşları (2010), doğumdan sonraki birinci ayı içinde olan annelerle yaptıkları MR çalışmalarında, bu annelerin, kendi çocukluklarında annelerinin bakım ve aşırı koruyuculuğuna yönelik algılarıyla bebek uyaranlarına verdikleri fonksiyonel yanıtın ilişkisi ölçülmüş̧ür. Çocukluk döneminde daha fazla anne bakımı gördüğünü belirten annelerin bebek ağlaması sırasında üst ve orta prefrontal alanlarda daha yüksek aktivasyon izlendiği, daha az anne bakımı gördüğünü söyleyen annelerde hipokampal aktivasyonlarda artış olduğu belirtilmiştir.

Swain çocuklarına örseleyici davranan annelerle yaptığı çalışmalarda, bu annelerin doğum sonrası ve ilerleyen zamanda görsel ve işitsel bebek uyaranlarına karşı abartılı fizyolojik tepkiler verdikleri izlenmiştir. Çalışmada, kortikal düzenlemelerin yetersiz kaldığ 1 durumda, bu annelerin, dürtüsel ve bastırılamamış tepkiler vermesi ya da uyaranların eşik altında kalarak ihmalde bulunmalarının olasılığı üzerinde durulmuştur (Swain, 2008; Swain, 2011).

Yıldırım ve arkadaşlarının, cinsel yakınmalarla başvuran iki kadın hasta ile yaptıkları terapötik çalışma sonucunda hasta yakınmalarının, kendi kız çocuklarına yönelik istismar riski kaygılarıyla ortaya çıktığı ve hastaların çocuklarıyla aynı yaştayken maruz kaldıkları çocukluk çağı cinsel istismar yaşantılarının bulunduğu anlaşıllmıştır. Bu annelerin kız çocuklarına yönelik 
davranışlarının da kendi anneleriyle olan ilişki biçimlerini yansıtır şekilde koruyucu ya da çatışmalı olduğu, bu haliyle annenin bir kaç kuşak önceki rol ve ilişkileri, çocuğun öznelliğini etkileyecek şekilde aktarmakta olduğu yönünde değerlendirilmiştir (Yıldırım, Peykan, Hacıoğlu, Koçak ve Özer, 2010).

Ayaz, Özpolat, Yücel ve Altunöz (2013), 3 yaşındaki kızının bekâreti konusunda endişeler yaşaması sonucu kompülsif davranış örüntüleri geliştiren ve kızının psikososyal gelişimine zarar veren bir annenin kliniğe yatışı sonrası tedavi sürecini izlemişlerdir. Bu annenin, obsesif kompulsif bozukluk (OKB) gelişiminde, çocukluk örselenmeleriyle birlikte reddedici, aşırı kontrolcü ve eleş̧irel ebeveyn tutumunun etkili olduğu, erken dönemde gelişen tehdit algısının kendi davranışları üzerinde kontrol duygusunu azalttığı ve duygularını düzenlemekte zorlandığı görülmüş̧ür. Annenin, çocukluğunda maruz kaldığı istismarcı anne rolünü devam ettirerek kendi kızını istismar etmeye devam ettiği yönünde raporlamışlardır.

Rijlaarsdam ve arkadaşları (2014), 6 yaş öncesi çocuğun içselleştirme ve dışsallaştırma davranış problemleri ile annenin çocukluk istismarı öyküsü arasındaki ilişkinin aracı mekanizmalarını araştırdıkları çalışmalarında, çocukların dışsallaştıııcı sorunlarında annenin düşmanca davranışlarının ve sert disiplinin etkili olduğunu bulgulamışlardır.

Ezen ve Aç1kgöz (2017), hastane personeli olan annelerle yaptıkları çalışmada, erken dönemde örselenme yaşantısına sahip annelerin, kendi çocuklarına daha fazla örseleyici davrandıkları, bu annelerin en yoğun olarak duygusal istismara maruz kaldıkları, çocuklarına ise yoğun olarak fiziksel istismarda bulundukları sonucuna ulaşmışlardır.

Kimi çalışmalarda, anne ile bebek/çocuk arasındaki bağlanma ilişkisinin niteliği çocuğun duygu düzenleme becerisinin öncülü sayılmış ve bağlanma kuramı, duygulanım düzenleme kuramı olarak değerlendirilmiş̧ir. Çocuğun bakım vereniyle kurduğu ilişkide duyguların karşılıklı olarak düzenlenmesi ve deneyimlenmesi, çocuğun kendi duygu düzenleme becerisinin gelişiminde ve buna bağlı olarak çocuğun işlevselliğinde ve iyilik durumunda önemli rol oynamaktadır (Özyurt, Öztürk ve Akay, 2017). Massart ve arkadaşları (2016), erken dönem deneyimlerin DNA metilasyonu üzerine yaptıkları araştırmada, annenin bakım ve ilgisinin biyokimyasal sinyallere çevrildiğini, bu sinyallerin genlerin ifadesini değiştirerek yavrunun sosyal çevreye uzun vadeli adaptasyonlarının şeklini belirlediğini göstermişlerdir. Yetersiz anne bakımı yada yoksunluğunun, hipokampüsteki glukokortikoid reseptörü üzerindeki olumsuz etkisiyle yavruların yaşam boyu davranışlarını değiştirerek anksiyete artışı ve stres tepkiselliğine neden olduğu, bu durumun ilerleyen dönemde prefrontal korteksin gelişimi ve bağışıklık sistemini de etkilediği görülmüştür (Massart ve ark., 2016; Weawer ve ark., 2004).

Küresel bir sorun olan çocuklara yönelik kötü muamelenin yaşam boyu süregiden ve insanların acı çekmesine neden olan sonuçları bulunmaktadır. Erken dönemde yaşanan kötü muamele yarattığı stres ile beyin gelişiminde bozulmalara yol açarak zihinsel, psikolojik ve davranışsal risk faktörlerine açık hale getirir. Bu risk faktörlerinden biri de çocukluğunda kötü muameleye maruz kalmış birinin ebeveyn ya da bakım veren olduğunda beraberindeki çocuğun kötü muameleye uğrama riskini artıracă̆ıdır (WHO, 2016). Çocukluk ihmal ve istismarı yaşamanın uzun vadeli etkileri hakkında farkındalık artmaktadır ancak bu mağduriyeti yaşamış çocukların ebeveynliği ve bir ebeveyn olduklarında kendi çocuklarının duygusal ve sosyal gelişimlerini nasıl etkileyecekleri hakkında çok az şey bilinmektedir (Treat, Sheffield, Willamson ve HaysGrudo, 2019). Bu sebeple, annelerin çocukluk örselenme yaşantısı ile çocukların duygusal ve sosyal gelişimlerinde yaşanan problemler arasındaki ilişkiye etki eden etmenlerin araştırılmasının önemli olduğu düşünülmüş ve söz konusu çalışma oluşturulmuştur.

Literatürde, örselenmelerin nörobiyolojisi ve davranış problemleri hakkında çok az araştırma yapıldığı (Hanson var ark., 2014), Türkçe literatürde ise oldukça az sayıda olduğu (Eşel, 2010; 
Ezen ve Açıkgöz, 2017; Fırat ve Baskak, 2012; Gökler ve Taner, 2004) görülmektedir. Bu alanda yapılan az sayıda çalışma, örselenme öyküsü bulunan annelerin çocukları ile ilişkisinin bebeklik döneminden itibaren zorlaşacağı ve gelişimin önemli basamaklarının sağlıksız yaşanacağı olasılığı üzerinde durmaktadır (Racine, Plamondon, Madigan, McDonald, Tough, 2018). Bu yönüyle, anne ve çocuk arasındaki ilişkinin nörogelişimsel mekanizmasının incelenmesi literatüre önemli bir katkı sağlayacaktır.

Bu araştırmada, 4-6 yaş aralığında duygusal ve sosyal açıdan uyum ve davranış sorunları yaşayan çocukların annelerinde, çocukluk örselenme yaşantısının varlığı araştırılmıştır. Ayrıca annelerin örselenme geçmişi ile annelerin duygu düzenleme becerisi ve çocuğuyla kurduğu ilişkinin niteliği arasındaki ilişkiler incelenmiştir. Çocukluk dönemi örselenmelerinin, uzun vadede, annenin duygu düzenleme süreçleri ve güvenli annelik davranışları üzerinde olumsuz etkiler yaratabildiği görülmüştür. Bu konuda, çocuklarla çalışan uzmanlar ve annelerde farkındalık oluşturmak, çocukluk travmalarının beyin ve ruh sağlığı üzerindeki olumsuz etkisini azaltarak duygusal ve sosyal dayanıklılığa ve güvenli ilişkilere geçişi destekleyen müdahalelerin geliştirilmesine katkıda bulunmak ümit edilmiştir.

\section{YÖNTEM}

\section{Araştırmanın Modeli}

Söz konusu araştırma ilişkisel tarama modelinde kesitsel bir çalışmadır. İlişkisel taramalar, değişkenler arasındaki ilişkileri incelemeyi ve varsayımda bulunabilmeyi sağlar (Büyüköztürk, Çokluk ve Köklü, 2011).

\section{Çalışma Grubu}

Araştırmada, 48 ay ile 72 ay arasında çocuk sahibi olan annelerden, çocuklarında problem davranışlar gözlemleyenlerin çalışmaya katılması istenmiştir. 4-6 yaş aralığının belirlenmesinde, literatürde 4 yaştan itibaren duyguyu ifade etme ve düzenleme becerisinin ortaya koyulma biçiminin gözlenebilmesi (Pollak ve ark., 2000) ve 6 yaştan sonra akademik yaşamın önemli bir etken olarak bu sürece dahil olması etkili olmuştur. Kocaeli ili İzmit ilçesi özel ve devlete bağlı anaokullarından basit tesadüfi örnekleme yöntemi kullanılarak 116 anne çalışmaya katılmıştır. Bu annelerden, çocuğun yaşı ve problem düzeyi araştırma kriterlerine uygun olmayan 41 cevap veri dışı bırakılmıştır ve 75 kişilik bir çalışma grubu oluşturulmuştur.

Çocuklarda gözlemlenen problem düzeyi, kişisel bilgi formunda sorgulanmıştır. Etik kurallar gereği çocukların ve devam etmekte oldukları okulların isimlerinin belirtilmemesi istenmiştir. DSM-V tanı ölçütleri (Amerikan Psikiyatri Birliği, 2013) doğrultusunda problemin çocuğun okul ve/veya sosyal çevresince son 6 aydır izleniyor olması, problemin şiddeti ve yaşa uygunluğu (Peacock ve Holland, 2003) dikkate alınmıştır.

Annelerin \%46.7'sinin çocuklarında öfkeye bağlı problemler yaşandığını belirttiği, çocukların \%9.3'ünün korkuya bağlı uyku sorunları yaşadığı, yine \%9.3'ünde regresyon bulunduğu, $\% 8$ 'inde yeme bozukluğu ve \%1.3'ünde takıntılı davranışlar gözlendiği ve \%25.3'ünde birden fazla problem davranışın bir arada bulunduğunun belirtildiği görülmüştür.

Araştırmaya katılan annelerin yaş ortalamasının $34.8 \pm 4.2$ olduğu, annelerin çocuklarının yaş ortalamasının ise $60.4 \pm 11.6$ aylık olduğu görülmüştür. Çocukların 42'sinin kız, 33'ünün ise erkek olduğu görülmüştür. Annelere ait demografik bilgiler Tablo 1'de verilmiştir. 
Tablo 1. Katılımcılara Ait Kişisel Bilgiler

\begin{tabular}{llcc}
\hline Değişken & & $\mathrm{n}$ & $\%$ \\
\hline Eğitim durumu & İlk ve ortaokul & 3 & 4 \\
& Lise & 16 & 21.3 \\
& Önlisans & 11 & 14.7 \\
& Lisans & 38 & 50.7 \\
& Lisansüstü & 7 & 9.3 \\
Çalışma durumu & Evet & 43 & 57.3 \\
& Hayır & 32 & 42.7 \\
Ortalama aylık gelir & $0-2500$ & 7 & 9.3 \\
& 2501-5000 & 22 & 29.3 \\
& 5001-7500 & 19 & 25.3 \\
& 7501-10000 & 12 & 16.0 \\
& 10001 ve üstü & 15 & 20.0 \\
Cocukluğunda kimin & Anne ve baba ile birlikte & 64 & 85.3 \\
yanında büyüdüğü & Yalnızca anne ile birlikte & 6 & 8.0 \\
& Aile büyükleriyle birlikte & 5 & 6.7 \\
\hline
\end{tabular}

Araştırmaya katılan annelerin bilgileri incelendiğinde; annelerin \%4'nün ilkokul ve ortaokul mezunu olduğu, \%36'sının lise ve ön lisans mezunu olduğu, \% 60'1nın ise lisans ve üstü öğrenim almış olduğu görülmüştür. Yine annelerin, \%36'sının 7500TL ve üstü aylık gelire sahip olduğu görülmüştür. Katılımcı annelerden 64'ünün çocukluğunda anne ve babasiyla birlikte büyüdüğünü belirttiği, 6 katılımcının yalnızca anne ile, 5 katılımcının ise aile büyükleriyle bir arada büyümüş olduğunu belirttiği görülmüştür.

\section{Verilerin Toplanması}

\section{Veri Toplama Araçlart}

Çalışmanın etik kurul izni, Üsküdar Üniversitesi Girişimsel Olmayan Araştırmalar Etik Kurulu Başkanlığı tarafindan 27/12/2019 tarih ve 61351342/2019-673 sayı ile verilmiştir. Akabinde verilerin toplanması amacıyla Kocaeli İl Milli Eğitim Müdürlügü’ne bağlı 6 Devlet okulundan veri toplamak için izin istenmiş ve 6 Mart 2020 tarihinde onay alınmıştır. Ancak yaşanan pandemi nedeniyle okullar bünyesinde veri toplanamamıştır. Bu sebeple veri toplama araçları, okul sınırlaması olmaksızın, Google formlar aracılığıyla annelere ulaştırılmıştır. Gönüllük esasına dayalı olarak katılımcılara, araştırmacı tarafından oluşturulmuş Gönüllü formu ve Kişisel bilgi formu, Çocukluk Örselenme Yaşantıları Ölçeği (Aslan ve Alparslan, 1999), Duygu Düzenleme Güçlüğü Ölçeği- Kısa Form (Yiğit ve Yiğit, 2017) ve Çocuk-Ana Baba İlişki Ölçeği (Akgün ve Yeşilyaprak, 2010) öz-bildirim ölçekleri uygulanmıştır.

\section{Kişisel Bilgi Formu}

Katılımcıların, sosyodemografik özelliklerini saptamak amacıyla araştırma değişkenleriyle ilgili olarak yapılandırılmıştır. Formda araştırmaya katılan annelerin yaşı, eğitim ve çalışma durumu, gelir düzeyi, annenin çocukluğunda kimin/kimlerin yanında büyüdüğü sorgulanmıştır. Formda araştırmaya katılan annelerin çocuklarının yaşı, cinsiyeti ve hangi tür duygusal ve davranışsal problem yaşandığ 1 ve problemin sıklığı ve şiddeti sorgulanmıştır. Ayrıca katılımcı annede psikiyatrik tanı varlığı dişlama kriteri olarak belirlenmiştir.

Çocukluk Örselenme Yaşantıları Ölçeği (ÇÖYÖ) 
Bernstein ve arkadaşları (1994) tarafından, 18 yaşından önceki örselenme yaşantılarını taramayı amaçlayan kendini-bildirim ölçeğidir. Ülkemizdeki geçerlik ve güvenirlik çalışması Aslan ve Alparslan (1999) tarafından üniversite öğrencileri üzerinde yapılmıştır. Örselenme yaşantılarının doğrudan söylenmediği dikkate alınarak profesyoneller için bir tanıma aracı ihtiyacını karşılamak amacıyla geliştirilmiştir. Ölçeğin, iç tutarlılık katsayısı Cronbach $\alpha=.96$, ölçeğin yarıya bölme güvenirlik katsayısı Cronbach $\alpha=.96$ olarak hesaplanmıştır. Ölçeğin duygusal kötüye kullanım ve duygusal ihmal, fiziksel kötüye kullanım, cinsel kötüye kullanım olmak üzere 3 alt boyutu bulunmaktadır. 3 Alt boyutun da iç tutarlılık kat sayıları Cronbach $\alpha=.94$ - .95 arasında hesaplanmıştır (Aslan ve Alparslan, 1999). Ölçek 40 maddeden oluşan 5'li Likert tipi ölçektir ve yüksek puanlar istismar yaşantısının varlığını göstermektedir. Ölçekten alınabilecek taban puan 40 ve tavan puan 200'dür (Aslan ve Alparslan, 1999). Bu araştırmada da Aslan ve Alparslan (1999)'ın çalışmasında olduğu gibi ÇÖYÖ 3 alt boyut üzerinden değerlendirilmiştir ve tüm alt boyutların güvenirlik düzeyleri kabul edilebilir olup, fiziksel istismar alt boyutu .85, duygusal istismar ve ihmal boyutu .94 ve cinsel istismar alt boyutu .79 düzeyinde bulunmuştur. Ölçek genelinde ise güvenirlik .94 olarak bulunmuştur.

\section{Duygu Düzenleme Güçlüğü Ölçeği-Kısa Form (DDGÖ-Kısa Form)}

Bjureberg ve arkadaşları (2016) tarafından geliştirilen ölçek duygu düzenlemedeki güçlük düzeylerini belirleme ve ölçmeyi hedeflemektedir. Ölçek 5'li likert tipinde ve 16 maddeden oluşmaktadır, yüksek puanlar duygu düzenleme güçlügünde yaşanan yoğunluğa işaret etmektedir. Ölçekten alınabilecek taban puan 16 ve tavan puan 80'dir. Ölçek, duygusal tepkilerin anlaşılmaması (Açıklık), olumsuz duyguların deneyimlendiği sırada amaca yönelik davranışlarda bulunmada güçlük yaşama (Amaçlar), olumsuz duygular deneyimlenirken dürtü kontrolünde güçlük yaşama (Dürtü), etkili olarak algılanan duygu düzenleme stratejilerine erişimde sinırlılık (Strateji), duygusal tepkilerin kabul edilmemesi (Kabul etmeme) alt boyutlarından oluşmaktadır (Yiğit ve Yiğit, 2017). Ölçeğin Türkçeye uyarlaması Yiğit ve Yiğit (2017) tarafından yapılmış ve iç tutarlılık katsayısı Cronbach $\alpha=.92$ olarak bulunmuştur. Ölçekte açıklık, amaçlar, dürtü, strateji ve kabul etmeme alt boyutları iç tutarlılık katsayıları sırasıyla $.84, .84, .87, .87$ ve .78 olarak bulunmuştur. Bu araştırmada da Yiğit ve Yiğit (2017)'in çalışmasında olduğu gibi, ölçek açıklık, amaçlar, dürtü, strateji ve kabul etmeme olmak üzere 5 alt boyut üzerinden değerlendirilmiştir ve sırasıyla güvenirlik katsayıları .88, .82, .89, .88, .84 olarak bulunmuştur. Ölçek genelinde ise güvenirlik .94 olarak bulunmuştur.

\section{Çocuk-Anababa İlişki Ölçeği}

Ölçek, Pianta (1992) yılında anne baba çocuk ilişkisini anlamak amacı ile anne çocuk etkileşimi literatüründen ve bağlanma teorisinden yararlanılarak oluşturulmuştur. Buna göre, bebeğin rahatlatılma, korunma, yatıştırılma ve keşfetme ihtiyacını karşılayan ebeveynler duyarlı ebeveynler olarak tanımlanır. Bu duygusal bağ sayesinde çocuk, güvenilir, sevilir ve değerli olduğuna dair bir zihinsel model inşa edecektir ve bu model yetişkinlikte de işlev görmeye devam edecektir (Akgün ve Yeşilyaprak, 2010). Ölçeğin uyarlama çalışması Akgün ve Yeşilyaprak (2010) tarafından, karşılıklı ilişkiye yönelik davranışların tanımlandığı bir ölçek ihtiyacıyla 4-6 yaş çocuk sahibi anneler örnekleminde yapılmıştır. Ölçek orjinalinde 3 alt boyuttan oluşmaktadır ancak bağlanma alt boyutunun iç tutarlılığı kültürel sebeplerin etkisiyle düşük bulunmuştur. Uyarlanan ölçekte Çatışmalı ilişki (.85) ve Olumlu/Yakın ilişki (.73) olmak üzere 2 alt boyut bulunmaktadır. Ölçek 5'li likert tipinde ve 24 maddeden oluşmakta ve toplam puan iç tutarlılık katsayısı Cronbach $\alpha=.73$ olarak bulunmuştur. Ölçek analizinde Olumlu/Yakın ilişki alt boyutu ters kodlanmakta ve alınan yüksek puanlar çatışmalı ilişkiyi göstermektedir (Akgün ve Yeşilyaprak, 2010). Ölçekten alınabilecek taban puan 24, tavan puan ise 120'dir.Bu araştırmada da Akgün ve Yeşilyaprak (2010)'ın çalışmasında olduğu gibi, ölçek yakın ve çatışmalı olmak üzere 2 alt boyut üzerinden değerlendirilmiştir ve yakın alt boyutun 
güvenirlik katsayısı .70, çatışma alt boyutunun güvenirlik katsayısı .80 olarak bulunmuştur. Ölçek genelinde ise güvenirlik .79 olarak bulunmuştur.

\section{Verilerin Analizi}

Katılımcılardan elde edilen veriler SPSS 16.0 programına aktarılmıştır. Öncelikle değişkenlere ilişkin betimsel istatistikler yapılmış ve değişkenlerin normallik testi için Skewness ve Kurtosis değerlerine bakılmıştır. Skewness ve Kurtosis değerleri -1.5 ile +1.5 aralığında olduğunda normal dağılım olduğu kabul edilmektedir (Tabachnick and Fidell, 2013). Mevcut çalışmada ÇÖYÖ, DDGÖ ve Çocuk Ana-baba ilişki ölçeğinin Skewness değerlerinin sırasıyla .897, .519, .198 olduğu, Kurtosis değerlerinin ise sırasıly .424, -.266, -.153 olduğu görülmüştür. Ölçek alt boyutlarının ise Skewness değerlerinin .003 ile 1.18 arasında değiştiği Kurtosis değerlerinin ise -.872 ile 1.19 arasında değiştiği görülmüştür. Yalnızca, ÇÖYÖ’nin cinsel istismar alt boyutunun normal dağılımdan anlamlı olarak farklılık sergilediği görülmüştür ve bu alt boyut için nonparametrik analizler olan, Spearman Brown korelasyon analizi ve Kruskal-Wallis testi kullanılmıştır. Normal dağılım gösteren, diğer tüm değişkenler arasındaki ilişkiyi izlemek amacıyla Pearson korelasyon analizi yapılmıştır. Katılımcıların çocukluk örselenme yaşantısının varlığının, kişisel bilgilerine göre farklılaşıp farklılaşmadıklarını görmek amacıyla yapılan anova analizinde, anlamlı farkların görüldüğü durumlarda, gruplar arası eşitsizlik nedeniyle homojen dağılım için Hochberg's GT2 Post hoc testi, ÇÖYÖ cinsel istismar alt boyutu için kullanılan Kruskal-Wallis analizinde ise, Tamhane's T2 Post hoc testi uygulanmıştır (Hochberg ve Tamhane, 1987).

İlişkili bulunan değişkenler arasında yordama gücü çoklu regresyon analizi ile test edilmiştir. Böylece, ÇÖYÖ’ne ait fiziksel istismar ve duygusal istismar alt boyutlarının DDGÖ’ne ait alt boyutlar olan açıklık, amaçlar, dürtü, strateji ve kabul etmeme üzerindeki yordama gücü ve Çocuk-Anababa İlişki Ölçeği Yakın ilişki alt boyutu üzerindeki yordama gücü incelenmiştir. Yine ilişkili bulunan DDGÖ'ne ait açıklık, amaçlar, dürtü, strateji ve kabul etmeme alt boyutlarının Çocuk-Anababa İlişki Ölçeği ortalaması ile Yakın ve Çatışmalı ilişki alt boyutları üzerindeki yordama gücü incelenmiştir.

\section{BULGULAR VE TARTIŞMA}

\section{Katılımcı Annelerin Çocukluk Örselenme Yaşantıları, Duygu Düzenleme Güçlüğü ve Çocuk-Anne İlişkisi Puanları ile İlişkili Demografik Faktörler}

Katılımcı annelerin örselenme yaşantısına sahip olma düzeyi incelendiğinde, örselenme yaşantısı puan ortalamalarının $73.01 \pm 24.05$ olduğu ve puanların birbirinden oldukça farklılaşabildiği görülmüştür. En yüksek örselenme yaşantısının duygusal istismar ve ihmal boyutunda var olduğu ve yine en yüksek düzeyde farklılaşmanın da bu boyutta ortaya çıktığı görülmüş̧ür. 8 katılımcının yüksek düzeyde cinsel istismar yaşantısına sahip olduğunu belirttiği, bu sayının katılımcı sayısı içinde \%10.6'lık bir oran oluşturduğu görülmüştür.

Yapılan Anova ve Kruskal Wallis testi analiz sonuçları Tablo 2'de gösterilmiştir. Anova analizinde, anlamlı farkların görüldüğü durumlarda, gruplar arası eşitsizlik nedeniyle homojen dağılım için Hochberg's GT2 Post hoc testi uygulanmıştır. ÇÖYÖ cinsel istismar alt boyutu, Kruskal Wallis testi ile analiz edilmiş olup, anlamlı farkların görüldügü durumda Tamhane's T2 Post hoc testi uygulanmıştır (Hochberg ve Tamhane, 1987). Katılımcı annelerin çocuklukta örselenme yaşantısı bulgusunun eğitim düzeylerine ve mevcut gelir durumlarına göre farklılık göstermediği ancak çocuklukta yanında büyünülen kimselere göre farklılık gösterdiği görülmüştür. 
Tablo 2.Annelerin Çocukluk Örselenme Yaşantılarına Etki Eden Demografik Faktörler $(\mathrm{N}=75)$

\begin{tabular}{|c|c|c|c|c|c|c|}
\hline \multirow[t]{2}{*}{ Değişkenler } & & \multirow{2}{*}{\multicolumn{2}{|c|}{$\begin{array}{l}\text { Fiziksel } \\
\text { İsitismar }\end{array}$}} & \multirow{2}{*}{$\begin{array}{l}\text { Duygusal } \\
\text { İstismar ve İhmal }\end{array}$} & \multirow{2}{*}{$\begin{array}{c}\text { ÇÖYÖ } \\
\text { Ortalama }\end{array}$} & \multirow{2}{*}{$\begin{array}{c}\text { Cinsel } \\
\text { İstismar }\end{array}$} \\
\hline & & & & & & \\
\hline \multirow[t]{4}{*}{ Eğitim durumu } & Grup içi & & 1.73 & 3.88 & 1.88 & \\
\hline & Gruplar arası & & 21.33 & 47.91 & 26.16 & $X^{2}=7.76$ \\
\hline & $\mathrm{F}$ & & 1.42 & 1.41 & 1.26 & \\
\hline & & $p$ & .236 & .237 & .293 & .101 \\
\hline \multirow{4}{*}{$\begin{array}{l}\text { Ortalama aylık } \\
\text { gelir }\end{array}$} & Grup içi & & .28 & 1.02 & .32 & \\
\hline & Gruplar arası & & 22.78 & 50.77 & 27.72 & $X^{2}=6.33$ \\
\hline & $\mathrm{F}$ & & .220 & .355 & .208 & \\
\hline & & $p$ & .927 & .840 & .933 & .176 \\
\hline \multirow{2}{*}{$\begin{array}{l}\text { Çocukluk } \\
\text { döneminde kimin } \\
\text { yanında }\end{array}$} & Grup içi & & 2.25 & 3.68 & 2.88 & \\
\hline & Gruplar arası & & 20.81 & 48.12 & 25.17 & $X^{2}=9.63$ \\
\hline \multirow[t]{2}{*}{ büyündüğü } & F & & 3.89 & 2.75 & 4.11 & \\
\hline & & $p$ & $.025^{*}$ & .070 & $.020 *$ & $.008 * *$ \\
\hline
\end{tabular}

Çocuklukta yalnızca anne yanında büyüdüğünü belirten katılımcıların, anne ve baba yanında büyüdüğünü belirten katılımcılara nazaran çocukluk örselenme yaşantısı ölçeğinin genel toplamında ve fiziksel istismar alt boyutunda daha yüksek puanlara sahip oldukları ancak aile büyükleri yanında büyüdüğünü belirten katılımcılardan farklılaşmadıkları görülmüştür. Çocuklukta aile büyükleri yanında büyüdüğünü belirten katılımcıların ise cinsel istismar boyutu puanlarının, anne ve baba yanında büyüdüğünü belirten katılımcılardan anlamlı düzeyde farklılaştığı ancak yalnızca anne yanında büyüdüğünü belirten katılımcılardan farklılaşmadığı görülmüştür. Duygusal istismar ve ihmal alt boyutu puanlarının ise, çocukluk döneminde yanında büyünülen kimselere göre farklılaşmadığı görülmüştür.

Katılımcı annelerin, duygu düzenleme güçlüğü puan ortalamalarının $40.6 \pm 14.84$ olduğu, tüm alt boyutların puan ortalamasının birbirine yakın olduğu ve dağılımlarının birbirine paralel olduğu görülmüsstür. Katılımcıların duygu düzenleme güçlüğü genel ve alt boyut puanlarının, demografik özelliklerine göre farklılık göstermediği bulunmuştur ( $p>0,05)$.

Katılımcı annelerin, çocuk-anne ilişkisi ölçek puan ortalamalarının 50.94 \pm 11.47 olduğu, Çatışmalı ilişki alt boyutu puan ortalamasının daha yüksek olduğu ve yine yüksek düzeyde farklılaşmanın da bu boyutta olduğu görülmüştür. Katılımcıların çocuk-anne ilişkisi genel ve alt boyut puanlarının, demografik özelliklerine göre farklılaşmadığı bulunmuştur $(p>0,05)$. 


\section{Katılımcı Annelerin Çocukluk Örselenme Yaşantıları, Duygu Düzenleme Güçlüğü Düzeyleri ve Çocuk-Anne İlişki Ölçeği Puanları Arasındaki Korelasyonlar}

Kullanılan ölçeklerin genel ve alt boyutlarını içeren tüm değiş̧kenlerin yer aldığı korelasyon analizi sonuçları Tablo 3'de verilmiştir. Buna göre, annelerin, çocukluk örselenme yaşantısının varlığı ile duygu düzenleme güçlügü puanları arasında yüksek anlamlılıkta ve pozitif yönde orta düzeyde bir ilişki ortaya çıkmıştır. Bununla birlikte, DDGÖ alt boyutlarından "kabul etmeme" boyutu ile çocukluk örselenme yaşantılarından yalnızca duygusal istismar ve ihmal alt boyutu arasında zayıf düzeyde anlamlı bir ilişki gözlemlenmiştir.

Tablo 3. Annelerin Çocukluk Örselenme Yaşantısı (ÇÖYÖ), Duygu Düzenleme Güçlüğü (DDGÖ) ve Çocuk-Anne İlişkisi Puanları Arasındaki Korelasyon (R) Değerleri (N =75)

\begin{tabular}{|c|c|c|c|c|c|c|c|c|c|c|c|c|c|}
\hline Değişkenler & 1 & 2 & 3 & 4 & 5 & 6 & 7 & 8 & 9 & 10 & 11 & 12 & 13 \\
\hline 1. ÇÖYÖ Ort & & $.867^{* *}$ & $.965^{* *}$ & $.353 * *$ & $.398^{* *}$ & $.374 * *$ & $.380^{* *}$ & $.330^{* *}$ & $.377 * *$ & .183 & .154 & $.284 *$ & .046 \\
\hline 2. Fiziksel İst & & & $.720 * *$ & $.192 *$ & $.357^{* *}$ & $.317 * *$ & $.347 * *$ & $.337^{* *}$ & $.359 * *$ & .097 & .134 & $.233^{*}$ & .056 \\
\hline $\begin{array}{l}\text { 3. Duygusal İst. ve } \\
\text { İhmal }\end{array}$ & & & & $.289 * *$ & $.353^{* *}$ & $.345 * *$ & $.339 * *$ & $.267^{*}$ & $.324 * *$ & $.195^{*}$ & .125 & $.279 *$ & .006 \\
\hline 4. Cinsel İst. & & & & & $.195^{*}$ & $.306^{* *}$ & .143 & .173 & .158 & .120 & $.261^{*}$ & $.298 * *$ & .173 \\
\hline 5. DDGÖ Ort. & & & & & & $.755^{* *}$ & $.769^{* *}$ & $.882 * *$ & $.928 * *$ & $.733^{* *}$ & $.367^{* *}$ & $.224 *$ & $.366^{* *}$ \\
\hline 6. Açıklık & & & & & & & $.562 * *$ & $.621 * *$ & $.631 * *$ & $.447^{* *}$ & $.430^{* *}$ & $.318^{* *}$ & $.390 * *$ \\
\hline 7. Amaçlar & & & & & & & & $.609^{* *}$ & $.642 * *$ & $.361^{* *}$ & $.282^{* *}$ & .089 & $.329 * *$ \\
\hline 8. Dürtü & & & & & & & & & $.788 * *$ & $.561^{* *}$ & $.326^{* *}$ & $.194 *$ & $.316^{* *}$ \\
\hline 9. Strateji & & & & & & & & & & $.608^{* *}$ & $.313^{* *}$ & $.204 *$ & $.310^{* *}$ \\
\hline 10. Kabul Etmeme & & & & & & & & & & & $.213^{*}$ & .157 & $.204 *$ \\
\hline 11.Çocuk-Anne & & & & & & & & & & & & & \\
\hline İliş. Ort. & & & & & & & & & & & & $.742 * *$ & $.906^{* *}$ \\
\hline 12.Yakın İliş. & & & & & & & & & & & & & \\
\hline 13.ÇatıșmalıI. & & & & & & & & & & & & & \\
\hline
\end{tabular}

${ }^{*} \mathrm{p}<.05, * * \mathrm{p}<.01$; korelasyonlar tek yönlü olarak hesaplanmıştır

ÇÖYÖ ile duygu düzenleme güçlüğü ortalaması anlamlı ve pozitif korelasyon $(r=.40 ; p<.01)$ göstermekte olup, duygu düzenleme güçlüğü alt boyutlarıyla olan ilişkisine bakıldığında $(\mathrm{r}=.33$ - .38; p<.01), ÇÖYÖ puanları arttıkça açıklık, amaçlar, dürtü ve strateji puanlarının da arttığ1 söylenebilir. Fiziksel istismar yaşantısının varlığı ile duygu düzenleme güçlüğü ortalama puanı ve kabul etmeme alt boyutu hariç diğer tüm alt boyut puanları arasında anlamlı ve pozitif yönde $(\mathrm{r}=.31-.35 ; \mathrm{p}<.01)$ bir ilişki bulgulanmış olup, fiziksel istismar yaşantısı puanları arttıkça açıklık, amaçlar, dürtü ve strateji puanlarının da arttı̆̆ı söylenebilmektedir.

Duygusal istismar ve ihmal yaşantısının varlığı ile duygu düzenleme güçlüğü ortalama puanı ile açıklık, amaçlar ve strateji alt boyutları arasında anlamlı ve pozitif yönde $(\mathrm{r}=.32-.35 ; \mathrm{p}<.01)$ bir ilişki bulgulanmıştır. Ayrıca, dürtü ve kabul etmeme alt boyutları ile anlamlı ancak daha zayıf bir ilişki $(r=.19-.26 ; \mathrm{p}<.05)$ olduğu görülmüştür. Cinsel istismar yaşantısının varlığı ile duygu düzenleme güçlüğü arasındaki ilişkiye bakıldığında, DDGÖ ortalaması ile arasında zayıf 
ancak anlamlı bir ilişki $(\mathrm{r}=.19 ; \mathrm{p}<.05)$ ve beş alt boyuttan yalnızca açıklık boyutu ile arasında yüksek anlamlılıkta ve pozitif yönde $(r=.30 ; p<.01)$ bir ilişkisi olduğu bulgulanmıştır.

Çocuk-anne İlişkisi ölçeği ile ÇÖYÖ arasındaki ilişki incelendiğinde, ilişki ölçeğinin genel ortalaması ile yalnızca cinsel istismar puanları arasında anlamlı ancak zayıf bir ilişkinin $(r=.26$; $\mathrm{p}<.05)$ varlığından söz edilebileceği, çatışmalı ilişki alt boyutu ile ÇÖYÖ ortalaması ve alt boyutları arasında anlamlı bir ilişkinin varlığından söz edilemeyeceği sonucuna varılmıştır.

Yakın ilişki alt boyutu ile ÇÖYÖ ortalaması ve fiziksel istismar ve duygusal istismar ve ihmal alt boyutlarının her biri arasında anlamlı ve pozitif yönde bir ilişki $(r=.23-.28$; $\mathrm{p}<.05)$ olduğu ancak ilişkinin gücünün zayıf olduğu görüşmüştür. Cinsel istismar alt boyutunun ise yüksek düzeyde anlamlı ve daha güçlü bir ilişkiye $(r=.30 ; p<.01)$ sahip olduğu görülmüştür.

Çocukluk örselenme yaşantıları varlığı ile Çocuk-Anne İlişkisi yakınlık alt boyutu puanlarının birlikte artma eğilimi gösterebildiği söylenebilir. Bu alt boyutun ters kodlanması dikkate alındığında, ÇÖYÖ puanları ile Yakınlık alt boyutu puanlarının negatif ilişkili olduğu söylenebilir.

DDGÖ ortalama puanı arttıkça Çocuk-Anne İlişkisi ölçeği ortalama puanının ve alt boyut puanlarının arttığı görülmektedir. DDGÖ alt boyutlarından açıklık, amaçlar, dürtü ve strateji boyutları ile Çocuk-Anne İlişkisi ölçeği ortalama puanı ve çatışma alt boyutu arasında yüksek anlamlılıkta ve orta düzeyde bir ilişki olduğu $(\mathrm{r}=.28-.43 ; \mathrm{p}<.01)$ ancak kabul etmeme boyutu ile aralarında daha zayıf bir ilişki $(\mathrm{r}=.20-.21 ; \mathrm{p}<.05)$ olduğu görülmektedir. Yakınlık alt boyutunun, amaçlar ve kabul etmeme alt boyutları ile ilişkili bulunmadığı, dürtü ve strateji alt boyutları ile arasında anlamlı ancak zayıf bir ilişki ( $\mathrm{r}=.19-.20 ; \mathrm{p}<.05)$ olduğu görülmektedir.

Açıklık alt boyutunun Çocuk-Anne İlişkisi ölçeği ortalama puanı ve alt boyutları ile en yüksek ilişki düzeyine sahip olduğu, çatışma alt boyutu ile arasında anlamlı bir ilişki $(r=.39 ; \mathrm{p}<.01)$ olduğu, yakınlık alt boyutu puanlarının ise yalnızca açıklık alt boyutu puanları ile yüksek anlamlılıkta ve daha güçlü bir ilişkiye sahip olduğu $(\mathrm{r}=.32 ; \mathrm{p}<.01)$ görülmüştür.

\section{Çocukluk Örselenme Yaşantıları Varlığının Duygu Düzenleme Güçlüğü Üzerindeki Yordayıcılı̆̆}

Çocukluk örselenme yaşantıları alt boyutlarından fiziksel istismar ve duygusal istismar ve ihmal varlığının, duygu düzenleme güçlügü üzerindeki etkinliğini ve yordamadaki katkılarını bağımsız olarak saptamaya çalışmak amacıyla çoklu regresyon analizi uygulanmıştır. Yapılan analiz sonuçları Tablo 4'te gösterilmiştir. ÇÖYÖ cinsel istismar alt boyutu normal dağılım göstermemesi sebebiyle analize dahil edilmemiştir. DDGÖ kabul etmeme alt boyutu ile yalnızca duygusal istismar ve ihmal alt boyutu puanları arasında anlamlı bir ilişki bulunmuş olması sebebiyle çoklu regresyon analizine dahil edilmemiştir. Bu iki alt boyut arasında yapılan regresyon analizi sonucunda ise duygusal istismar ve ihmal alt boyutunun, kabul etmeme alt boyutu üzerinde anlamlı bir yordayıcılığının olmadığı (Beta=.19; p>.05) görülmüştür.

Yapılan analizde birinci basamakta yer alan fiziksel istismar değişkeninin DDGÖ toplam puanlarını anlamlı olarak yordadığı $(B$ eta $=.35 ; \mathrm{p}<.05)$ ve fiziksel istismar yaşantısının varlı̆̆ arttıkça annelerin duygu düzenleme güçlüğü puanlarının arttığı ve söz konusu değişkenin varyansın \%11'ini açıkladığı görülmektedir. İkinci basamakta eklenen duygusal istismar ve ihmal değişkeninin DDGÖ toplam puanları üzerinde tek başına anlamlı düzeyde yordayıcılığının bulunmadığı ve toplam varyansa \%1'lik katkı sağladığı görülmüştür. 
Tablo 4. ÇÖYÖ ve Annelerin Duygu Düzenleme Güçlügü̈ (DDGÖ) Ortalamalarının Çoklu Regresyon Analizi $(\mathrm{N}=75)$

\begin{tabular}{|c|c|c|c|c|c|c|c|c|c|c|c|c|c|c|c|}
\hline & \multicolumn{2}{|c|}{ DDGÖ ort. } & \multicolumn{3}{|c|}{ Açıklık } & \multicolumn{4}{|c|}{ Amaçlar } & \multicolumn{3}{|c|}{ Dürtü } & \multicolumn{3}{|c|}{ Strateji } \\
\hline & B & $\mathrm{SH}$ & $\beta$ & B & $\mathrm{SH}$ & $\beta$ & B & $\mathrm{SH}$ & $\beta$ & B & $\mathrm{SH}$ & $\beta$ & B & $\mathrm{SH}$ & $\beta$ \\
\hline \multicolumn{16}{|l|}{ Yordayıcılar } \\
\hline \multicolumn{16}{|l|}{ Model 1} \\
\hline Sabit & 1.52 & .32 & & 1.37 & .39 & & 1.93 & .39 & & 1.07 & .41 & & 1.26 & .37 & \\
\hline Fiziksel & .59 & .18 & $.35^{*}$ & .62 & .22 & $.31^{*}$ & .68 & .21 & $.34^{*}$ & .71 & .23 & $.33^{*}$ & .68 & .20 & $.35^{*}$ \\
\hline \multicolumn{16}{|l|}{ İstismar } \\
\hline $\mathrm{R}^{2}$ & .12 & & & .10 & & & .12 & & & .11 & & & .13 & & \\
\hline$\Delta \mathrm{R}^{2}$ & .11 & & & .09 & & & .11 & & & .10 & & & .12 & & \\
\hline \multicolumn{16}{|l|}{ Model 2} \\
\hline Sabit & 1.47 & .32 & & 1.29 & .39 & & 1.87 & .39 & & 1.05 & .42 & & 1.21 & .37 & \\
\hline Fiziksel İstismar & .35 & .26 & .21 & .28 & .31 & .14 & .42 & .31 & .21 & .63 & .34 & .30 & .49 & .30 & .26 \\
\hline \multirow{3}{*}{$\begin{array}{l}\text { Duygusal İstisma } \\
\text { ve İhmal }\end{array}$} & .22 & .17 & .19 & .31 & .21 & .24 & .24 & .20 & .18 & .07 & .22 & .05 & .17 & .20 & .13 \\
\hline & .14 & & & .13 & & & .13 & & & .11 & & & .14 & & \\
\hline & .12 & & & .10 & & & .11 & & & .09 & & & .11 & & \\
\hline
\end{tabular}

$* \mathrm{p}<.05$

Birinci basamakta, fiziksel istismar değişkenin açıklık alt boyutu puanlarını anlamlı olarak yordadığ $1(B e t a=.31 ; p<.05)$ ve varyansın \%10'unu açıklayabildiği, ikinci basamakta eklenen duygusal ihmal ve istismar değişkeninin ise anlamlı düzeyde yordayıcılığının bulunmadığı görülmüş̧ür.

Fiziksel istismar değişkenin, amaçlar alt boyutu puanlarını anlamlı olarak yordadığ (Beta $^{\prime} .34$; $\mathrm{p}<.05)$ ve puanlarının birlikte artma eğilimi gösterdiği, söz konusu değişkenin varyansın \%11'ini açıklayabildiği ancak ikinci basamakta eklenen duygusal istismar ve ihmal değişkeninin ise amaçlar boyutu puanları üzerinde değişiklik yaratmadığı görülmüştür. Dürtü alt boyutunun regresyon analizinde ise, birinci basamakta fiziksel istismar değişkeninin anlamlı düzeyde yordama gücü olduğu $(B e t a=.33 ; p<.05)$ ve varyansın $\% 10$ 'unu üzerinde tek başına etkili olduğu görülmüştür. Yine strateji alt boyutunda, fiziksel istismar değişkeninin anlamlı düzeyde yordama gücü olduğu $(B$ eta $=.35 ; \mathrm{p}<.05)$ ve varyansın $\% 12$ 'si üzerinde tek başına etkili olduğu görülmüştür. Dürtü ve strateji boyutlarının her iki analizinde de ikinci basamakta eklenen duygusal ihmal ve istismar değişkeninin bu boyutlar üzerinde doğrudan açıklama gücünün sınırlı olduğu, bununla birlikte toplam varyans üzerinde $\% 1$ oranında etkiyi azalttığ görülmüştür.

\section{Çocukluk Örselenme Yaşantıları Varlığının Çocuk-Anne İlişki Ölçeği Puanları Üzerindeki}

\section{Yordayıcılığı}

ÇÖYÖ cinsel istismar alt boyutu normal dağılım göstermemesi sebebiyle analize dahil edilmemiştir. Fiziksel istismar ve duygusal istismar ve ihmal alt boyutu puanları ile Çocukanne ilişki ölçeği ortalama puanları ve çatışmalı ilişki alt boyutu puanları arasında anlamlı düzeyde korelasyonel bir ilişki bulunmaması sebebiyle analize dahil edilmemişlerdir. 
Tablo 5. ÇÖYÖ ve Çocuk-Anne İlişkisi Ölçeği Yakın Ilişki Alt Boyutu Ortalamasının Çoklu Regresyon Analizi (N=75)

$$
\text { Yakın İlişki }
$$

\begin{tabular}{lccc} 
Yordayıcılar & B & SH & $\beta$ \\
\hline Model 1 & 1.59 & .17 & \\
Sabit & .19 & .09 & $.23^{*}$ \\
Fiziksel İstismar & & & \\
Model 2 & 1.55 & .17 & .06 \\
Sabit & .05 & .13 & .23 \\
Fiziksel İstismar & .13 & .09 &
\end{tabular}

${ }^{*} \mathrm{p}<.05 \quad$ Model 1 için; $\mathrm{R}^{2}=.05 \quad \Delta \mathrm{R}^{2}=.04 \quad$ Model 2 için; $\mathrm{R}^{2}=.08 \quad \Delta \mathrm{R}^{2}=.05$

Birinci basamakta yer alan fiziksel istismar değişkeninin yakın ilişki alt boyutundaki puanları anlamlı olarak yordadığ $1($ Beta $=.23 ; \mathrm{p}<.05)$ ve fiziksel istismar yaşantısının varlığı arttıkça annelerin çocuklarıyla yakın ilişki puanlarının arttığı ve böylece ilişkinin çatışmalıya doğru evrildiği görülmektedir. Ancak bu model, varyansın yalnızca \%4'ünü açıklayabilmektedir.

İkinci basamakta eklenen duygusal istismar ve ihmal değişkeninin yakın ilişki alt boyutundaki puanlar üzerinde tek başına anlamlı düzeyde yordayıcılığının bulunmadığı ve toplam varyansa \%1.3'lük katkısının olduğu görülmüştür.

\section{Duygu Düzenleme Güçlüğü Puanlarının Çocuk-Anne İlişki Ölçeği Puanları Üzerindeki Yordayıcılığı}

Tablo 6'da gösterilen regresyon analizinde Yakınlık alt boyutunun amaçlar ve kabul etmeme alt boyutları ile arasında anlamlı bir ilişki bulunmaması nedeniyle yordama güçleri yakınlık alt boyutunda analiz edilmemiştir. Yapılan analizin birinci basamağında yer alan duygu düzenleme güçlüğü ölçeği açıklık boyutunun, ilişki ölçeği genel ortalaması üzerinde anlamlı düzeyde yordayıı (Beta $=.43 ; \mathrm{p}<.01$ ) etkiye sahip olduğu ve varyansın \%17'sini açıklayabildiği görülmüştür. Yine bu basamakta açıklık boyutu değişkeni, çatışmalı ilişki puanları üzerinde $($ Beta $=.39 ; \mathrm{p}<.01)$ ve yakın ilişki puanları üzerinde $(\mathrm{Beta}=.32 ; \mathrm{p}<.01)$ yüksek düzeyde anlamlı yordama etkisine sahip olup, çatışmalı ilişki boyutunda varyansın \%14'ünü ve yakın ilişki boyutunda ise varyansın \%9'unu açıklama gücüne sahiptir. 
Tablo 6. DDGÖ ve Çocuk-Anne İlişkisi Ölçeği Ortalamalarının Çoklu Regresyon Analizi (N=75)

\begin{tabular}{|c|c|c|c|c|c|c|c|c|c|}
\hline \multirow{2}{*}{ Yordayıcılar } & \multicolumn{3}{|c|}{ İlişki Ölçeği ort. } & \multicolumn{3}{|c|}{ Yakın İlişki } & \multicolumn{3}{|c|}{ Çatışmalı İlişki } \\
\hline & B & SH & $\beta$ & B & SH & $\beta$ & B & SH & $\beta$ \\
\hline \multicolumn{10}{|l|}{ Model 1} \\
\hline Sabit & 1.67 & .12 & & 1.59 & 1.26 & & 1.79 & 1.73 & \\
\hline Açıklık & .18 & .04 & $.43 * *$ & .13 & .06 & $.32 * *$ & .23 & .06 & $.39 * *$ \\
\hline $\mathrm{R}^{2}$ & .18 & & & .10 & & & .15 & & \\
\hline$\Delta \mathrm{R}^{2}$ & .17 & & & .9 & & & .14 & & \\
\hline \multicolumn{10}{|l|}{ Model 2} \\
\hline Sabit & 1.62 & .16 & & & & & 1.62 & .22 & \\
\hline Açıklık & .16 & .06 & $.36^{*}$ & & & & .16 & .09 & .27 \\
\hline Amaçlar & .01 & .06 & .03 & & & & .08 & .09 & .14 \\
\hline Dürtü & .03 & .07 & .09 & -.00 & .07 & -.01 & .03 & .10 & .06 \\
\hline Strateji & .00 & .09 & .00 & .00 & .08 & .01 & .00 & .12 & .00 \\
\hline Kabul etmeme & -.00 & .05 & -.01 & & & & -.00 & .08 & -.04 \\
\hline $\mathrm{R}^{2}$ & .19 & & & .10 & & & .17 & & \\
\hline$\Delta \mathrm{R}^{2}$ & .13 & & & .6 & & & .11 & & \\
\hline
\end{tabular}

$* \mathrm{p}<.05, * * \mathrm{p}<.01$

Duygusal tepkilerin anlaşılmaması durumunu ölçmeyi hedefleyen açıklık boyutu puanlarındaki artış, ilişki ölçeği genel ve alt boyutlarındaki puanların çatışma yönünde artmasına yol açmaktadır. Analizin ikinci basamağında yer alan açıklık boyutu dışında kalan duygu düzenleme güçlüğü alt boyutlarının çocuk-anne ilişki ölçeği ortalama ve alt boyutları puanlarını yordama gücünün anlamlı düzeyde olmadığı görülmüştür. Bununla birlikte amaçlar, dürtü, strateji ve kabul etmeme alt boyutlarının analize katılımıyla birlikte açıklık boyutunun, çocukanne ilişki ölçeği ortalama ve alt boyutlarının puanlarını yordama etkinliğinin zayıfladığı görülmüştür.

\section{TARTIŞMA}

Çocukluk çağı örselenmeleri tarih boyunca var olmuş, bilinen en büyük küresel sorunlardan biri olmaya devam etmektedir. Çocukluk çağı olumsuz yaşantıları, çocuğu bedensel ve ruhsal olarak zorlayan olaylardır. Tarihi eski olmakla birlikte çocukluk örselenmelerinin yaşam boyu sağlık ve refah üzerine ileriye dönük etkileri ise çok daha geç yıllarda konuşulmaya başlanmıştır. Bu örselenmelerin ebeveynlik davranışları üzerinde yaratacağı etki ise çok daha yakın zamanda bilimsel çalışmaların konusu olmaya başlamıştır. Gelişimsel travmalar çocuklukta ve devamındaki yetişkinlikte bir dizi bozukluğun ortaya çıkmasında önemli bir etiyolojik sebep gibi görünmektedir. Yeni araştırmalar, çocuklukta kötü muameleye maruz 
kalmanın anneden yavrularına aktarım ile örselenmenin kuşaklararası aktarımı üzerine yoğunlaşmaktadır.

Çocukların yaşadığı gözlemlenebilir problemlerin birçok sebebi olmakla birlikte, ebeveyne yönelik çalışmaların yoğun olarak tutum, bağlanma biçimi, değer algısı ve son yıllarda duygu düzenleme stratejileri üzerine yoğunlaştığı görülmektedir (Ezgin ve Dilmaç, 2018; Soysal, Bodur, İşeri ve Şenol, 2005; Taner ve Başal, 2013; Tüzün ve Sayar, 2006). Söz konusu çalışmada ise, çocuklarda gözlemlenen problemlerin, uyumlanma ve bağlanmayı içeren anneçocuk ilişkisinin niteliğine ve bu ilişkinin doğasını oluşturduğu kabul edilen annenin dinamiklerine odaklanılmıştır. Söz konusu dinamikler ise, çocukluk örselenme yaşantısı ve duygu düzenleme güçlüğü olarak belirlenmiştir. Annelerde çocukluk örselenmesinin varlığg ve bu örselenmelerin duygu düzenleme üzerine bozucu etkisi az araştırılan dinamiklerden biri olması sebebiyle seçilmiştir.

Çalışmanın demografik verilerinin analizinde, katılımcı annelerin çocuklukta örselenmeye maruz kalma oranlarının, sahip oldukları eğitim, gelir düzeyi ve çalışma durumu gibi mevcut sosyoekonomik durumlarına göre farklılık göstermediği bulunmuştur. Katılımcıların içinde büyüdüğü sosyoekonomik durum, mevcut durumlarından farklılık gösterebileceği gibi, çocukluk örselenmeleri her sosyodemografik yapı içinde görülebilmektedir. Çocukluk dönemi cinsel istismarının ise, annenin eğitim düzeyi ve annede depresyonun varlığıyla güçlü bir ilişkisi olduğu saptanmıştır (Çelik ve Hocaoğlu, 2018). Böylece anneye ait demografik faktörlerin önemli bir risk etmeni olduğuna işaret edilmiştir. Mevcut araştırmada, fiziksel ve cinsel istismara uğrama oranının yalnızca anne yanında ya da aile büyükleri yanında büyüdüğü durumlarda arttığı görülmüştür. Buradan yola çıkarak anne ve babanın birlikteliğinde büyümenin koruyucu etkisi olduğu ve bu birlikteliğin ebeveynler için de destekleyici olduğu söylenebilir.

Annelere ait duygusal istismar ve ihmal alt boyutu puanlarının, annelerin demografik özelliklerine göre ve çocukluk döneminde yanında büyüdüğ̈ kimselere göre farklılaşmadığı görülmüştür. Bilindiği gibi duygusal istismar tek başına yaşanabileceği gibi, diğer istismar türlerine eşlik de etmektedir. $\mathrm{Bu}$ durum, duygusal istismarın sonuçlarının birebir gözlenebilmesini güçleştirmiştir. Duygusal istismar yaşantısının tek başına ele alındığ çalışmalarda, bu istismar türünün sonuçlarını araştırmak daha mümkün olacaktır.

Sekiz katılımcının yüksek düzeyde cinsel istismar yaşantısına sahip olduğunu belirttiği, bu sayının katılımcı sayısı içinde \%10.6'lık bir oran oluşturduğu görülmüştür. Dünya Sağlık Örgütü'nün raporunda her 5 kadından 1'inin cinsel istismara maruz kaldığg 1 (WHO, 2016) ve yine ülkemizde 7-18 yaş aralığında yapılan araştırmada, çocukların \%10'nun cinsel istismara tanıklık ettiği bildirilmiştir (UNICEF-Türkiye, 2010). Bu yönüyle katılımcıların bildirdiği cinsel istismara maruz kalma oranının, raporlarla örtüşen oranlarda olduğu görülmüştür. Ülkemizde, cinsel istismarın ifade edilmesinin ve/veya ortaya çıkarılmasının toplumsal dinamiklerce zorlaştı̆̆ 1 genel kanısına nazaran, mevcut çalışmada bu sinırlılığın yaşanmadığı, bu konularda yapılan araştırmaların sayısının artması ve toplumun konuşmaya teşvik edilmesinin baskı ve sınırlılıkları azaltıcı etki ettiği yönünde değerlendirilmiştir.

Araştırmada duygu düzenleme güçlüğü puanları incelendiğinde, katılımcıların puanlarının birbirine yakın olduğu, demografik bilgilerine göre anlamlı farklılık göstermediği görülmüştür. $\mathrm{Bu}$ durumda, katılımcı annelerin eğitim düzeyinin yüksek olmasının etkili olabileceği düşünülmüştür. Anne eğitim düzeyi ve ebeveynlik biçimleri üzerine yapılan çalışmalarda, annenin eğitim düzeyi arttıkça kontrolcü uygulamalarının azaldığı (Moorman ve Pomerants, 2008) görülmüştür. Bu annelerin, çocuğun ihtiyaç ve beklentilerine daha duyarlı davranışlar geliştirebileceği muhtemeldir. 
Gelişimsel travmalara dair yapılan pek çok araştırma, erken dönemdeki örselenmelerin, nöral gelişim üzerindeki etkisinin sosyo-duygusal davranışları deneyime bağlı olarak şekillendirebildiğini ve bu durumun genetik hassasiyet ve olumsuz çevre koşullarından bağımsız şekilde psikopatolojinin yordayıcısı olarak ortaya çıktığını bildirilmektedir (Calkins ve Hill, 2007; De Bellis, 2005; Grant ve ark., 2011). Yine bu sonuçlar da, duygu düzenleme güçlügünün demografik değişkenlerden bağımsız olarak gelişebileceğini ve bu gelişimin, ilk ilişkiler içinde tekrara bağlı olarak oluştuğunu göstermektedir. Mevcut araştırmada, annelerin sahip olduğu çocukluk örselenme yaşantısı arttıkça, annelerin duygu düzenleme güçlüğünde anlamlı bir artışa sebep olacağı öne sürülmüştür. Yapılan analizlerin öne sürülen ilişkiyi destekler nitelikte olduğu ve yapılan çalışmalarla tutarlılık gösterdiği sonucuna ulaşılmıştır.

Araştırmada, annelerin duygu düzenleme güçlüğü puanları üzerinde yüksek yordama gücüne sahip olan çocukluk örselenmeleri şeklinin, fiziksel istismara ait olduğu görülmüştür. Bilindiği gibi, hemen her kültürde ve ülkemizde çocuğa fiziksel şiddet uygulamak sık rastlanan durumlardan biridir ve bu durumun kabul görmesini sağlayan kültürel dinamikler bulunmaktadır. Çalışmalar, fiziksel istismara maruz kalan çocukların duyguları anlama, tanıma ve ifade etme gibi sorunlarla karşı karşıya kaldıklarını göstermektedir (Pollak ve ark., 2000). Yine bu mağduriyeti yaşamış çocukların ilerleyen yıllarda sosyal ilişkilerde bozulmalar yaşadıkları, şiddeti sorun çözme yöntemi olarak kullanmayı öğrendiklerinde kendilerinin de şiddet uygulayan bir eş ya da ebeveyn olabildikleri görülmüştür (Çelik ve Hocaoğlu, 2018; Sarı ve ark., 2016). Araştırmalara paralel olarak mevcut çalışmada da, annelerin duygu düzenleme güçlüğü puanları arttıkça, anne ile çocuk arasındaki ilişkide çatışma puanlarının arttığı görülmüştür. Beklenildiği düzey de olmasa da, anlamlı olarak bu iki değişkenin birlikte artış gösterdiği, duyguyu düzenleyememenin kişilerarası ilişkilere zarar verdiği görülmüştür. Anne ile çocuk arasındaki ilişki de, diğer sosyal ve kişilerarası ilişkilerde olduğu gibi duyguyu tanıma, anlama ve sağlıklı ifade etme becerilerine ihtiyaç duyacaktır ve çocuğun bu becerileri edinmesinde ilk ilişkilerin önemi gün geçtikçe anlamlı hale gelmektedir. Çalışmalar, ebeveyn bebek ilişkisinin, bebeklere ilk sosyal ortamlarını sağlayarak, diğerlerinden ne bekleyeceklerine, onlarla girecekleri etkileşimin nasıl olacağına, başkalarının beklentilerini en iyi nasıl karşılayacaklarına ve nasıl bir ebeveyn olacaklarına dair şablonlar sunacağını göstermektedir (Swain ve ark., 2007; Swain, 2008). Bununla birlikte bu şablonlar, çocuğun kişiliğinin dirençli birer parçasını (Tüzün ve Sayar, 2006) oluşturmaktadır. Çocuğun sosyal yaşamın içine karışmaya ve okul ortamıyla tanışmaya başladığı 4-6 yaş aralığında duygusal ve sosyal becerileri daha görünür hale gelmeye başlamaktadır, kimi zaman aile içinde önemsizleştirilen ya da görmezden gelinen uyumsuz davranışların, okul ve çevrenin dikkat odağına girdiği söylenebilir.

DDGÖ’nün yalnızca Açıklık (duygusal tepkilerin anlaşılmaması) alt boyutunun, Çocuk-Anne İlişki ölçeği yakınlık ve çatışmalı alt boyutlarının her ikisi üzerinde ileriye dönük ve güçlü olarak tahmin gücü olduğu görülmüştür. Annenin çocuğu ile uyumlanma ve sağlıklı bağ kurabilme kapasitesi, çocuktan gelen mesajları ve duygusal ipuçlarını alabilme ve uygun cevaplar oluşturabilme becerisine bağlı görünmektedir. Yine çocuğun da, bu yolla, sosyal ipuçlarını erkenden tanıyarak yorumlayabilmesi ve davranışsal cevaplar oluşturabilmesi için duyguları tanıyabilmesi oldukça önemlidir (Perry, 2009; Pollak, Cicchetti, Hornung ve Reed, 2000; Shore, 2012; Siegel, 2018; Sümer, Sayıl ve Berument, 2016). Diğgerlerinin duygularına uygun alg1, deneyim ve yanıt verme olarak tanımlanan empatinin (Swain, 2011) ortaya çıkabilmesi için de elzem olan bu becerilerin gelişimi, büyük oranda bebeklik dönemindeki ebeveyn duyarlılığıyla ilişkili görünmektedir.

Anne ve çocuk arasındaki uyumlanma ve duyguların paylaşımı, ilerleyen süreçte çocuğun hissedildiğini hissetmesine olanak sağlayarak bu süreçte öğrenilenler bir başkasını hissedebilme ve içsel uyumlanmayı şekillendirir (Siegel, 2018). Anne ve çocuk arasındaki 
eşzamanlı uyumlanma çocuğun öz düzenlemesi ve sosyal strese uyumlu fizyolojik tepkiler verebilmesi için gerekli kişilerarası duygusal eş düzenlemeye (co-regulation) katkı sağlar (Azhari ve ark., 2019). Tüm bu açıklamalar erken çocukluk döneminde olan çocukların duygusal ve sosyal uyumunun ilişki içinde olduğu anneden beslendiğini göstermektedir. Anneler ilişki içinde oldukları çocuğun duyguyu düzenleme güçlüklerine odaklanmak ve kontrol etmekten daha çok kendi duygularını düzenleme konusunda yaşadığı zorlukların farkına varmalı ve buraya odaklanmalıdır. Bu noktada anneler ile yapılacak olan farkındalık çalışmalarının, hamilelik ve lohusalık gibi erken dönemlere yayılmasının, anne ve çocukların daha sağlıklı duygu düzenleme stratejileri geliştirmelerine yardımcı olacağı düşünülmektedir.

48-60 aylık çocuklarda gözlemlenen davranış problemleri ile çocukların anneleriyle olan ilişkilerinin incelendiği benzer bir çalışmada, çocukların anneleriyle kurduğu yakın ilişkinin çocuğun problem davranışlarında azaltıcı etkiye sahip olduğu, bu durumda çocuğun problem davranış sergilediği sırada gösterilen sıcak, yakın ve cevaplayıcı olmalarının da etkili olduğu görülmüştür. $\mathrm{Bu}$ araştırmada, anneyle çocuk arasındaki çatışmalı ilişkinin problem davranışlarda artışa sebep olduğu görülmüştür (Usta, 2014).

Araştırmada, çocukluk örselenme yaşantıları ile anne-çocuk ilişkisi arasındaki ilişki incelendiğinde, çatışma alt boyutu puanlarının örselenme yaşantısının varlığından bağımsız olduğu ancak yakın ilişki alt boyutu puanları ile ÇÖYÖ genel ortalaması ve tüm alt boyutlarının birlikte artış gösterdiği görülmüştür. Cinsel istismara maruz kalmanın ise, diğer istismar yaşantılarına nazaran yakın ilişki puanlarının artması (puanların artması olumsuz olduğunu göstermektedir) ile daha anlamlı bir ilişkiye sahip olduğu görülmüştür. Yapılan çalışmalarca, erken dönemde maruz kalınan cinsel istismar yaşantısının ileri yaşlardaki en önemli sonuçlarından birinin, ilişki kurma ve sürdürebilme becerisinin bozulması olduğu ve psikiyatrik tanılar içinde en sık majör depresyon ile ilişkili olduğu bildirilmiştir (Gökler ve Taner, 2004; Koçak ve Alpaslan, 2015). Cinsel istismarın aile içinde yaşanmış olması, çocuk üzerinde daha olumsuz ve uzun süreli etkilere sahiptir (Trickett, Noll, Reiffman ve Putnam, 2001). Çünkü, çocuk hayatta kalmak için ihtiyaç ve güven duyduğu kimselerce istismar edildiğinde, temel güven duygusu sarsılır ve korunmasız hisseder. Bu durum aile içinde yaşandığında tekrarlayıcı olma riski yüksektir ve çocuğun çaresiz hissetmesine neden olabileceği gibi yardım arayışını zorlaştıracağı düşünülmektedir.

Çocuk-Anne ilişki ölçeğinin "Çocuğumla etkileşimim, benim bir ebeveyn olarak kendimi etkili ve özgüvenli hissetmemi sağlar." şeklindeki son maddesine verilen puanların, örselenme yaşantısının varlığında arttığı gözlemlenmiştir. Fitzgerald ve arkadaşlarının (2005), ensest mağdurlarıyla yaptığı çalışmada, bu mağduriyeti yaşamış annelerin ebeveynlik becerilerine ilişkin algılarının var olan ebeveynlik ilişkilerinden daha olumsuz olabileceği sonucuna ulaşılmıştır. Bu durumun, cinsel istismar mağduru çocuklarda, maruz kaldığ eylem nedeniyle, kendini suçlama ve güçsüz hissetme duygularıyla (Soylu, Pilan, Ayaz ve Sönmez, 2012) örtüştüğü, bu çocukların, yetişkin olduklarında girdikleri yakın ikili ilişkilere aynı duyguları aktarabildiği yönünde değerlendirilmiştir.

Epidemiyolojik araştırmalar, yoksunluk, ihmal ve istismar öyküsü olan ebeveynlerin sağlık, eğitim, çocuklarında psikiyatrik problemler ve aile üyeleriyle ilişki problemleri yaşama gibi aile hayatının tüm aşamalarında problemler yaşadıklarını ve ebeveynlerin çatışmalı geçmişlerinin çocuklarıyla ilişkisine nüfuz edebildiğini göstermektedir (Fonagy, Steele M., Moran, Steele ve Higgitt, 1993). Görünen o ki, ebeveynlik davranış1, insan bebeklerinin şimdiki ve gelecekteki davranışlarını kritik olarak şekillendirmektedir. Geçmiş çalışmalarla tutarlı olarak bu çalışma da çocukluk örselenme yaşantıları ile duygu düzenleme güçlügü ve çocukanne ilişkisinin niteliği arasında ayrı ayrı birer ilişki olduğunu göstermiştir. Annenin ruh sağlığının, çocuğun duygusal ve sosyal uyumunun önemli bir parçası olduğu ve erken çocukluk dönemi klinik çalışmalarında bu odağın korunmasının gerekliliği, literatüre bir katkı olarak 
sunulduğu düşünülmektedir. Literatürde yer alan çocuklara yönelik kötü muamele araştırmaları gibi, söz konusu çalş̧ma da, bu alanda önleme, müdahale ve etkili politikalar oluşturmayı hedeflemektedir.

\section{SONUÇ VE ÖNERILLER}

Araştırmalar yoluyla ortaya konulmaya çalış1lan tüm davranışsal ilişkiler mikro ve makro sistemlerin bütününün katılımını gerektirmektedir. Bu haliyle diğer çalışmalar gibi bu çalışma da bütünü kapsayamadığı için eksiklikler barındırmaktadır. Araştırmadaki örneklem sayısının küçüklüğü ve katılımcıların demografik özelliklerinin homojenlik barındırması, istatistiki sonuçları anlamlı kılsa da ilişkinin gücü ve yordayıcıllğ̆ hakkında bilgi edinilmesini sınırlamıştır. Bu durum araştırma sonuçlarını genellemeyi de zorlaştırmaktadır.

Anne ve çocuk ilişkisini etkileyen birçok faktör sayılabilmektedir. İlişkisel davranışları tek bir nedene bağlamak mümkün olamayacağı gibi karıştırıcı faktörlerin çokluğu araştırmadaki olası yordayıcıların da gücünü zayıflatabilmektedir. Alandaki çalışmalar çocukluk örselenmelerinin ebeveynlik davranışları üzerine olumsuz etkisine kanıt niteliğinde bilgiler sunmakta olup, örselenmenin kişinin yalnızca kendi trajedisini oluşturmadığ kabul görmeye başlamıştır. Bu çalışmada sınanan iliş̧kiler için yeterli düzeyde destekleyici bulguya ulaşılamasa da yapılan farklı çalışmaların destekleme gücünün bulunduğu görülmüştür. Anne ve çocuk arasındaki ilişkilerin daha iyi anlaşllabilmesi için boylamsal çalışmalara ihtiyaç olduğu görülmüştür. Yine yapılacak benzer çalışmalarda kontrol grubunun oluşturulması, karşılaştırma yapma imkanı sunacağından daha sağlıklı sonuçlar alınmasına yardımcı olabilir.

Mevcut araştırmada, annenin çocuğuyla olan ilişkisini daha çok kendi gözlemlerine dayanarak aktarmasının sübjektif bir etki yaratacağı ve özellikle ihmal ve istismar yaşantısının varlığında kişinin kendi iç gerçekliği üzerindeki yanıltıcı etkinin dış gerçeklikle uyumsuzluk gösterebileceği ve yanlılık oluşabileceği bu araştırmanın sınırlılıkları arasındadır. Verilerin online olarak toplanması, gözetim ve gerekli müdahalelerin yapılmasını sınırlamıştır.

İlişkisel araştırmaların niteliksel olmanın yanında deneysel ya da gözleme dayalı olması daha objektif sonuçlar ortaya çıkmasını sağlayabilir. Ev içi, okul ya da laboratuvar gibi ortamlarda gözlem yoluyla ilişkinin içeriğinin not edildiği çalışmalar bulunmaktadır. Ancak buradaki bir diğer sorun da, ülkemizde ev içi gözlemlerin misafir ağıllamaya dönüştürülmesi gibi, doğal gözlem olanağını sınırlayıcı etkilerinin olmasıdır.

Çocukluk dönemi örselenmelerinin sonuçları ve ebeveynlik üzerine etkileri konusunda farkındalık yaratılması, yine örselenmelerin etkilerinin azaltılması ve gelecek kuşaklara aktarımının önlenebilmesi için gerekli erken müdahalelerin sağlanabilmesi, halk sağlığı adına elzem görünmektedir. Bu doğrultuda, anne-çocuk ilişkisinin nörobiyolojik mekanizmasını anlamak, annelik davranışlarına ilişkin bütüncül bir bakış açısı kazandıracak ve hem annenin hem gelişmekte olan çocuğun duygusal ve bilişsel sağlığı üzerinde daha etkili adımlar atılmasını sağlayacaktır. Tüm istismar türlerinin kiş̧inin ruh sağlığı, yakın ilişkileri ve sosyal yaşamı üzerinde güçlü olumsuz etkilere sahip olduğu bilinmektedir. Çocukluk dönemi cinsel istismarının ise, bu olumsuzluklarla birlikte kişinin temel güven duygusunu zedelediği, bu mağduriyeti yaşamış olan annelerin çocuklarıyla sıcak ve güvenli bir ilişki yaşamasının önüne geçebildiği görülmektedir. Bu noktada, ebeveynin sahip olduğu psikolojik durum hakkında bilinçli farkındalığının sağlanmasına yönelik müdahalelerde bulunmak ve anne ile çocuğun birlikte güvenli ve onarıcı ilişkiler yaşamalarına firsat verecek klinik müdahalelerde bulunmak iyileşme olanağı sunabilir. 


\section{KAYNAKÇA}

Akgün, E. ve Yeşilyaprak, B. (2010). Çocuk anababa ilişki ölçeği Türkçe formunun geçerlik ve güvenirlik çalışması. BAÜ Sosyal Bilimler Enstitüsü Dergisi, 13(24): 44-53.

Amerikan Psikiyatri Birliği (2013). Ruhsal bozuklukların tanısal ve sayımsal elkitabı. Beşinci Baskı (DSM-5). Ertuğrul Köroğlu (Çev.Ed.). Ankara: Hekimler Yayın Birliği.

Aslan, S. ve Alparslan, Z. N. (1999). Çocukluk örselenme yaşantıları ölçeğinin bir üniversite öğrencisi örnekleminde geçerlik, güvenirlik ve faktör yapısı. Türk Psikiyatri Dergisi, 10(4): 275- 285.

Ayaz, T., Özpolat, A.Y., Yücel, D. ve Altunöz, U. (2013). Kendi çocuğunu fiziksel olarak istismar eden ve kendisi de fiziksel istismar gören bir OKB vakası. Bilişsel Davranışçı Psikoterapi ve Araştırmalar Dergisi, 2: 116-120.

Azhari, A., Leck, W.Q., Gabrieli, G., Bizeego, A., Rigo, P. ... Esposito, G. (2019). Parenting stress undermines mother-child brain to brain synchrony: Ahperscanning study. Scientific Reports, 9: 11407.

Bernstein, DP., Fink, L., Handelsman, L., Foote, J., Lovejoy. ... Ruggiero, J. (1994). Initial reliability and validity of a new retrospective measure of child abuse and neglect. Am J Psychiatry; 151 (8): 1132-6.

Bertan, M., Haznedaroğlu, D., Koln, P., Yudakök, K. ve Güçiz, D.B. (2009). Ülkemizde erken çocukluk gelişimine ilişkin yapılan çalışmaların derlenmesi. Çocuk Sağliğl ve Hastalıkları Dergisi, 52: 1-8.

Bjureberg, J., Ljótsson, B., Tull, M.T., Hedman, E., Sahlin, H., Lundh, L.G. ... Gratz, K.L. (2016). Development and validation of a brief version of the difficulties in emotion regulation scale: The DERS-16. Journal of Psychopathology and Behavioral Assessment, 38(2): 284-296.

Büyüköztürk, Ş., Çokluk, Ö. ve Köklü, N. (2011). Sosyal bilimler için istatistik. Ankara: Pegem Akademi.

Calkins, S. D. ve Hill, A. (2007). Caregiver influences on emerging emotion regulation: Biological and environmental transactions in early development. In J. J. Gross (Eds.).Handbook of emotion regulation içinde (p. 229-248). New York: The Guilford Press.

Çelik, F.G.H. ve Hocaoğlu, Ç. (2018). Çocukluk çağı travmaları: Bir gözden geçirme. Sakarya Tip Dergisi, 8(4): 695-711.

De Bellis, M.D. (2005). The psychobiyology of neglect. Child Maltreatment, 10(2): 150-172.

Eşel, E. (2010). Anneliğin nörobiyolojisi. Türk Psikiyatri Dergisi, 21(1): 68-78.

Ezen, M. ve Açıkgöz, A. (2017). Çocukların örselenmesine annelerin örselenme yaşantısının etkisi. Kocaeli Medical J, 6(3): 13-21.

Ezgin, F. ve Dilmaç, B. (2018). Uyum ve davranış problemi gösteren çocukların ebeveynlerinin değer algılarına ilişkin görüşleri. Uluslararası Toplum Araştırmaları Dergisi, 8(15): 719774.

Felitti, V.J. (2009). Adverse childhood experiences and adult healt. Academic Pediatrics, 9: 131-2.

Fırat, S. ve Baskak, B., (2012). Gelişimsel travmanın uzun dönem etkileri ve bunlara aracılık eden nörobiyolojik mekanizmalar. Kriz Dergisi, 20: 25-41.

Fitzgerald, M.M., Shipman, K.L., Jackson, J.L., McMahon, R.J. ve Hanley, H.M. (2005). Perceptions of parenting versus parent-child interactions among incest survivors. Child Abuse Neglet, 29(6): 661-81. 
Fonagy, P., Steele, M., Moran, G., Steele, H. ve Higgitt, A. (1993). Measuring the ghost in the nursery: An empirical study of the relation between parents' mental representations of childhood experiences and their infants' security of attachment. J. Amer. Psychoanal. Assn., 41: 957-989.

Fraiberg, S., Adelson, E. ve Shapiro, V. (1975). Ghost in the nurcery: A psychoanalytic approach to the problem of impaired infant-mother relationships. Journal of the American of Child Psychiatry, 14(3): 387-421.

Gökler, B. ve Taner, Y. (2004). Çocuk istismarı ve ihmali: Psikiyatrik yönleri. Hacettepe Tip Dergisi, 35: 82-86.

Grant, M.M., Cannistrac, C., Hollon, S.D., Gore, J. ve Shelton, R. (2011). Childhood trauma history differentiates amygdala response to sad faces within MDD. J Psychiatr Res., Jul, 45(7): 886-95.

Hanson, L.J., Nacewicz, B.M., Sutterer, M.J., Cayo, A.A., Schaefer, S.M. ... Pollak, S.D. (2014). Behavioral problems after early life stress: Contribution of the hippocampus and amygdala. Biological Psychiatry, 15, 77(4): 314-23.

Hochberg, Y. ve Tamhane, A.C. (1987). Multiple comparison procedures. New York: John Wiley \& Sons press.

Kara, B., Biçer, Ü. Ve Gökalp, A.S. (2004). Çocuk istismarı. Çocuk Sağlı̆̆l ve Hastalıkları Dergisi, 47: 140-151.

Karabekiroğlu, A., Karabekiroğlu, K., Cömert, G. ve Topçuoğlu, V. (2007). Panik bozukluğunda beyin görüntüleme çalışmaları. Anadolu Psikiyatri Dergisi, 8(3): 224-230.

Kim, P., Leckman, J.F., Mayes, L.C., Newman, M., Feldman, R. ve Swain, J.E. (2010). Perceived guality of maternal care in childhood and structure and function of mother's brain. Dev. Sci., 13(4): 662-673.

Koçak, U. ve Alpaslan, A.H. (2015). Cinsel istismara uğrayan çocuk ve ergenlerin sosyodemografik özellikleri ve ruhsal değerlendirmesi. Adli Tıp Bülteni, 20(1): 27-33.

Lynch, M. (1999). Çocuk istismarı ve ihmali. Ankara: Çocuk İstismarı ve İhmalini Önleme Derneği.

Massart, R., Nemoda, Z., Suderman, J.M., Sutti, S., Ruggiero, A.M., Detter, A.M. ... Szyf, M.(2016). Early life adversity alters normal sex-dependent developmental dy-namics of DNA methylation. Dev. Psychopathol., 28(4pt2): 1259-1272.

Moorman, E. ve Pomerantz, E.M. (2008). Mothers' cognitions about children's self-control: Implications for mothers' responses to children's helplessness. Social Development, 17(4): 960-979.

Özyurt, G., Öztürk, Y., Akay, A. (2017). Anksiyete bozukluğu olan çocuklarda duygu düzenlemenin annelerin duygu düzenlemesi, bağlanma ve anksiyete duyarlılığ 1 ile lişkisinin incelenmesi. Anadolu Psikiyatri Dergisi, 18(4): 369-378.

Peacock, G. G. ve Holland, M. L. (2003).Emotional and behavioral problems of young children: Effective interventions in the preschool and kindergarten years. New York: Guilford Press.

Perry, B.D. (2000). Traumatized children: How childhood trauma influences brain development. The Journal of the California Alliance for the Mentally, III(11:1): 48-51.

Perry, B.D. (2001). The neurodevelopmental impact of violence in childhood. D. Schetky and E.P. Benedek (Eds.), Chapter 18: In textbook of child and adolescent forensic psychiatry içinde (p. 221-238). American Psychiatric Press.

Perry, B.D. (2002). Childhood experience and the expression of genetic potential: What childhood neglect tells us about nature and nurture. Brain and Mind,(3): 79-100.

Perry, B.D. (2009). Examining child maltreatment through a neurodevelopmental lens: Clinical applications of the neurosequential model of therapeutics. Journal of Loss and Trauma, 14(4): 240-255. 
Pianta R. C. (1992). Child-Parent Relationship Scale. University of Virginia. Author. Pietromonaco P. R. \& Barrett L. F. (2000). The Internal Working Models Concept: What Do We Really Know About The Self in Relation To Others?. Review of General Psychology, 4(2): 155-175.

Pollak, S.D., Cicchetti, D., Hornung, K. ve Reed, A. (2000). Recognizing emotion in faces: Developmental effects of child abuse and neglect. Developmental Psychology, 36(5): 679-688.

Racine, N., Plamondon, A., Madigan, S., McDonald, S. ve Tough, S. (2018). Maternal adverse childhood experiences and infant development. Pediatrics, 141(2): e20172495.

Rijlaarsdam, J., Stevens, G.W., Jansen, P.W., Ringoot, A.P., Jaddoe ... J.J., Tiemeier, H. (2014). Maternal childhoodmaltreatment and offspring emotional and behavioral problems: Maternal and paternal mechanisms of risk transmission. Child Maltreat, 19(2): 67-78.

Sarı, H.Y., Ardahan, E. ve Öztornacı, B.Ö. (2016). Çocuk ihmal ve istismarına ilişkin son 10 yılda yapılan sistematik derlemeler. TAF Preventive Medicine Bulletin, 15: 6.

Schore, A.N. (2012). Gelişimsel nörobiyoloji ve bağlanma kuramı. Tahir Özakkaş (Ed.). İstanbul: Psikoterapi Enstitüsü Eğitim Yayınları.

Schore, A.N. (2013). Duygulanımın düzenlenmesi ve kendiliğin kökeni: Duygusal gelişimin nörobiyolojisi. Tahir Özakkaş (Ed.), Kısım 3: Geç Bebeklik Dönemi içinde (s. 221-303). İstanbul: Psikoterapi Enstitüsü Eğitim Yayınları.

Siegel, D.J. (2018). Zihnin gelişimi: İlişkiler ve beyin arasındaki etkileşim bizi nasıl biz yapar?. Tahir Özakkaş (Ed.). İstanbul: Psikoterapi Enstitüsü Eğitim Yayınları.

Soylu, N., Pian, B.Ş., Ayaz, M. ve Sönmez, S. (2012). Cinsel istismar mağduru çocuk ve ergenlerde ruh sağlığını etkileyen etkenlerin araştırılması. Anadolu Psikiyatri Derg, 13: 292-298.

Soysal, A.Ş., Bodur, Ş., İşeri, E. ve Şenol, S. (2005). Bebeklik dönemindeki bağlanma sürecine genel bir bakış. Klinik Psikiyatri, 8: 88-99.

Sümer, N., Sayıl, M. ve Berument, S.K. (2016). Anne duyarlılı̆̆ı ve çocuklarda bă̆lanma. İstanbul: Koç Üniversitesi Yayınları: Özel Dizi-2.

Swain, J.E., Lorberbaum, J.P., Köse, S. ve Strathearn, L. (2007). Brain basis of early parentinfant interactions: Psychology, physiology, and in vivo functional neuroimaging studies. The Journel of Child Psychology and Psychiatry, 48 (3-4): 262-287.

Swain, J.E. (2008). Baby stimuli and the parent brain: Functional neuroimaging of the neural substrates of parent-infant attachment. Psychiatry (Edgmont (Pa. : Township)), 5(8): 2836.

Swain, J.E. (2011). The human parental brain: In vivo neuroimaging. Prog Neuropsychopharmocol Biol Psychiatry, 35(5): 1242- 1254.

Tabachnick, B. G. ve Fidell, L. S. (2013). Using multivariate statistics. Boston: Pearson.

Taner, M.D. ve Başal, H. (2013). Okulöncesi çocuklarında gözlenen davranış problemleri ile ailelerinin anne-aaba tutumları arasındaki ilişki. Amasya Üniversitesi Ë̆itim Fakültesi Dergisi, 2(1): 115-144.

Tanrıdağ, O. (2018). Çocuk beyninin gelişimi ve nörogelişimsel problemler. Fatma Özten (Ed.). İstanbul: Üsküdar Üniversitesi Yayınları.

Tottenham, N., Hare, T.A., Millner, A., Gilhooly, T., Zevin, J.D. ve Casey, B.J. (2011). Elevated amygdala response to faces following early deprivation. Dev Sci., 14(2): 190-204.

Treat, A.E., Sheffield-Morris, A., Williamson, A.C. ve Hays-Grudo, J. (2019). Adverse childhood experiences and young children's social and emotional development: The role of maternal depression, self-efficacy, and social support. Early Child Development and Care, doi: 10.1080/03004430.2019.1578220. 
Trickett, P.K., Noll, J.G., Reiffman, A. ve Putnam F.W. (2001). Variants of intra familial sexual abuse experience: Implications for short- and long-term development. Dev Psychopathol,13: 1001-1019.

Tüzün, O. ve Sayar, K. (2006). Bağlanma kuramı ve psikopaloji. Düşünen Adam, 19(1): 24-39.

UNICEF. (2008). Annual Report. Erişim adresi:https://www.unicef.org/publications/files/ UNICEF_Annual_Report_2008_EN_072709.pdf. Erişim tarihi: 10.10.2019.

UNICEF-Türkiye. (2010). Türkiye'de çocuk istismart ve aile içi şiddet araştırmast. Erişim adresi: http://atud.org.tr/kutuphane/unisefrapor.pdf. Erişim tarihi: 10.10.2019.

Usta, S.Y. (2014). Okul öncesi dönem çocuklarda davranış problemlerinin anne-çocuk ve ögretmen-çocuk ilişkileri açısından incelenmesi. Yüksek Lisans Tezi. Hacettepe Üniversitesi Eğitim Bilimleri Enstitüsü, Ankara.

Weawer, I.C.G., Cervoni, N., Champagne, F.A., D’Alessio, A.C., Sharma, S. ... Meaney, M.J. (2004). Epigenetic programming by maternal behaviour. Nature Neuroscience, 7(8): 847854.

World Health Organization. (2016). Child maltreatment. Erişim adresi: http://www.who.int/mediacentre/factsheets/fs150/en/. Erişim tarihi: 10.11.2020.

Yıldırım, E.A., Peykan, G., Hacıoğlu, H., Koçak, Y.E. ve Özer, Ş. (2010). Çocukluk çağı cinsel travması olan iki olguda travma belirtilerinin ortaya çıkışında anne olmalarının etkisi. Nöropsikiyatri Arşivi, 47: 174-7.

Yiğit, İ. ve Yiğit, M. G. (2017). Psychometric properties of Turkish version of difficulties in emotion regulation scale-brief form (DERS-16). Current Psychology,1-9. 